\title{
Absorptive capacity in startups: A systematic literature review
}

\section{Ximena Alejandra Flechas Chaparro ${ }^{1}$ (D), Ricardo Kozesinski', and Alceu Salles Camargo Júnior ${ }^{3}$}

\begin{abstract}
Purpose: Several scholars have pointed out that absorptive capacity (AC) is critical for the innovation process in large firms. However, many other authors consider startups as key drivers for innovation in the current global economy. Therefore, this article aims to identify how the concept of AC has been addressed in the new venture context. Methodology: A systematic literature review analyzing 220 papers published between 2001 and 2018. Findings: The systematic literature review identifies three clusters of research addressing AC in startups: Knowledge, Innovation, and Performance, along with the central authors of the discussion, the main contributions, theoretical references, and their future research agenda guidelines. Implications for theory and practice: This study contributes to the innovation and entrepreneurship literature by connecting the importance of AC and new venture creation, and providing a better understanding of how entrepreneurs could enhance their innovative processes. Originality and value: Based on the analysis of the literature review, a framework that differentiates knowledge acquisition strategies for new ventures was created. The framework categorizes the strategies according to the knowledge source (i.e., internal or external) and the degree of intentionality (i.e., formal or informal).

Keywords: innovation, absorptive capacity, startups, new ventures, entrepreneurship
\end{abstract}

1 Ximena Alejandra Flechas Chaparro, Ph.D. student. Faculty of Economics, Administration, and Accounting, University of São Paulo, Brazil. Avenida Professor Luciano Gualberto, 908 - Butantã - São Paulo/SP - 05508-010, Brazil, e-mail: xaflechas@usp.br (ORCID: https://orcid.org/0000-0002-4561-7122).

${ }^{2}$ Ricardo Kozesinski, Ph.D. candidate. Faculty of Economics, Administration, and Accounting, University of São Paulo, Brazil. Avenida Professor Luciano Gualberto, 908 - Butantã - São Paulo/SP - 05508-010, Brazil, e-mail: ricardo@rika.com.br ${ }^{3}$ Alceu Salles Camargo Júnior, Associate Professor at the Faculty of Economics, Administration, and Accounting, University of São Paulo, Brazil. Avenida Professor Luciano Gualberto, 908 - Butantã - São Paulo/SP - 05508-010, Brazil, e-mail: alceu@usp.br (ORCID: https://orcid.org/0000-0002-2370-9595).

Received 10 September 2019; Revised 12 February 2020, 25 March 2020, 29 May 2020, 8 December 2020; Accepted 15 December 2020.

This is an open access article under the CC BY license (https://creativecommons.org/licenses/by/4.0/legalcode). 


\section{INTRODUCTION}

Absorptive capacity (AC) is defined by Cohen and Levinthal (1990) as the ability to recognize, identify, assimilate and exploit new external information, and is considered to be critical for the innovation process. Zahra and George (2002, p. 186) defined AC as a "set of organizational routines and processes" including acquisition (to identify and obtain external knowledge), assimilation (to interpret and understand the information obtained), transformation (to integrate and combine existent knowledge with the newly acquired), and exploitation (the application of new knowledge for commercial ends). This ability involves renewing routines, practices, technological paths (March, 1991; McGrath, 2001), but in particular, it involves a learning process (Lane, Koka, \& Pathak, 2006).

Previous works have addressed extensively how organizations might benefit from AC. For instance, Patterson and Ambrosini (2015) explored how AC could be configured to support research activities in biopharmaceutical firms, Engelen and colleagues (2014) identified how AC contributes to the strengthening of the entrepreneurial orientation and a firm's performance relationship, and Lis and Sudolska (2015) studied what role AC plays in organizational growth and competitive advantage. The large number of theoretical and empirical publications addressing the AC construct over the past 30 years has also led to a number of literature reviews with different aims, such as revalidating and reconceptualizing the construct (e.g., Lane et al., 2006; Zahra \& George, 2002), identifying major discrepancies among AC's theoretical perspectives (e.g., Volberda, Foss, \& Lyles, 2010), and analyzing the multifaceted dimensions of AC literature (e.g., Apriliyanti \& Alon, 2017).

However, unlike these past reviews, in the present study, we propose to analyze $A C$ in the context of new ventures, mainly due to two factors. First, because several authors have argued that startups are better suited to develop radical innovation (Bower \& Christensen, 1995; Edison, Smørsgård, Wang, \& Abrahamsson, 2018; Spencer \& Kirchhoff, 2006). According to Giardino et al. (2014, p. 28), startups are entities "exploring new business opportunities, working to solve a problem where the solution is not well known and the market is highly volatile." These organizations are characterized by a lack of resources, rapid evolution, small teams, little working experience, third-party dependency, and work under several uncertainties (Giardino et al., 2014). Despite the shortcomings associated with the scarcity of resources and experience (Ambos \& Birkinshaw, 2010), these firms are able to launch innovative products and become a 'game-changer' in traditional industries, putting incumbent firms under pressure (Edison et al., 2018; Sirén, Hakala, Wincent, \& Grichnik, 2017). Second, because, despite being game-changers, 
startups operating in technology-intensive industries suffer the permanent threat of premature obsolescence since -and considering the high level of uncertainty- these companies often bet on 'failed technologies' (i.e., those technologies that result not to be the ones adopted by the market (Eggers, 2012) and to survive, they must revamp their knowledge to adjust their solutions for which the AC may be crucial. Therefore, we identified a necessity to analyze $A C$ literature within the context of new ventures in order to better understand which topics have been studied in this regard, and try to identify which aspects can be extracted from the main findings to contribute to some extent to the improvement of entrepreneurs' processes of knowledge renewal and innovation.

The aim of our research is to determine how the concept of $A C$ has been addressed in the new venture context by identifying the clusters of research, the main authors, and findings. To this end, we proceeded to conduct a systematic literature review analyzing 220 papers published between 2001 and 2018. Three clusters of research regarding the importance of $A C$ in the new venture context were identified: Knowledge, Innovation, and Performance. In addition, the central authors of the discussion were reviewed, including their main contributions, theoretical references, and future research agenda.

The text is structured as follows: section 2 reviews the concepts and discussions about dynamic capabilities and new ventures, followed by the methodology in section 3 . Our results are presented in section 4 , including the bibliometric and content analyses. In section 5 , we discuss the findings, and the last section contains the conclusions and suggestions for future research.

\section{LITERATURE BACKGROUND}

Authors such as Zahra and George (2002) and Engelen et al. (2014) have recognized AC as a dynamic capability. Dynamic capabilities (DC) enable the firm to evolve and positively influence its competitive advantage (Zahra \& George, 2002, p. 185). Given that the present study seeks to connect concepts from the strategic management (i.e., AC and DC) and entrepreneurship fields, it is important to discuss in which way this interaction could be addressed considering the still ongoing debate about these concerns (Arend, 2014). Teece, Pisano, and Shuen (1997, p. 516) defined DC as "the firm's ability to integrate, build and reconfigure internal and external competences to address rapidly changing environments." DC is tied to the resource-based theory, in which firms' differences, such as resources, skills or endowments, are key aspects that help companies to create a sustainable competitive advantage (Barney, 1991). However, DC complements the resource-based theory by 
providing the abilities for controlling, configuring, and reconfiguring the resources for long-term survival.

According to Teece et al. (1997), resources and assets are arranged in integrated groups of individuals that perform the firms' activities or routines. In other words, through functions, routines, and competences, firms take advantage of their resources. However, differently from incumbent firms, new ventures lack functions and routines, so they need to rely broadly on team members' and entrepreneurs' idiosyncratic knowledge to operate (Bergh, Thorgren, \& Wincent, 2011). In this regard, literature offers some examples of how DC has been addressed focused on individuals. For instance, Teece (2012) points out that there is a group of DC that is based on the individual "skills and knowledge of one or a few executives rather than on organizational routines" (Teece, 2012, p.1). According to the author, capabilities are built jointly by individual skills and collective learning originating from employees working together. In addition, the author notes that entrepreneurial management, besides being concerned about the improvement of existent routines, is more about creating new ones and figuring out new opportunities. Finally, Teece mentioned that the dependency on individual skills usually fades over time after five or ten years.

The individual approach in DC is associated with the concept of microfoundations, which are one of the aspects that undergird the capabilities. According to Teece (2007, p. 1319), micro-foundations are the mechanisms through which sensing, seizing, and reconfiguring capacities operate; these include "the distinct skills, processes, procedures, organizational structures, decision rules, and disciplines." Certainly, all these mechanisms widely depend on individual cognition (Helfat \& Peteraf, 2015) and individuals' extant knowledge (Teece, 2007). Helfat and Peteraf (2015) suggest that individual cognitive capabilities may mediate the relationship between changes in the organizational environment and strategic changes, and, therefore, individuals (by the effect of their own capacities) can reshape their organizations.

Several scholars have also discussed DC from the entrepreneurship perspective (for instance, Arend, 2014; Arthurs \& Busenitz, 2006; Boccardelli \& Magnusson, 2006; Newbert, 2005; Zahra, Sapienza, \& Davidsson, 2006). These works offer different alternatives to connect both of the research strands (i.e., DC and entrepreneurship). For instance, Newbert (2005) proposes the new firm formation process as a dynamic capability, based on a random sample of 817 entrepreneurs; he concludes that there is evidence to support that new firm creation meets the DC conditions placed by Eisenhardt and Martin (2000) (i.e., identifiable, unique, deals with market dynamism, and is affected by learning). Arthurs and Busenitz (2006) set out that after the opportunity identification, when entrepreneurial leadership starts to transition to a more 
formal type of management, new ventures need to develop new skills -as mentioned by Teece (2012)- through the usage of DC. Furthermore, Arend (2014) found out that most entrepreneurial ventures have been created based on DC from the beginning, and mainly on an individual level.

\section{RESEARCH METHODS}

With the aim of determining how the concept of AC has been addressed in the startups' context, we conducted a systematic literature review (SLR). This methodology is a rigorous and well-defined approach that enables the identification of the current knowledge and what is known about a given topic (Boell \& Cecez-Kecmanovic, 2015). Following Denyer and Neely (2004), we endeavored to develop an accurate process considering the planning, the use of explicit and reproducible selection criteria, and an analysis procedure. Figure 1 summarizes our systematic review process.

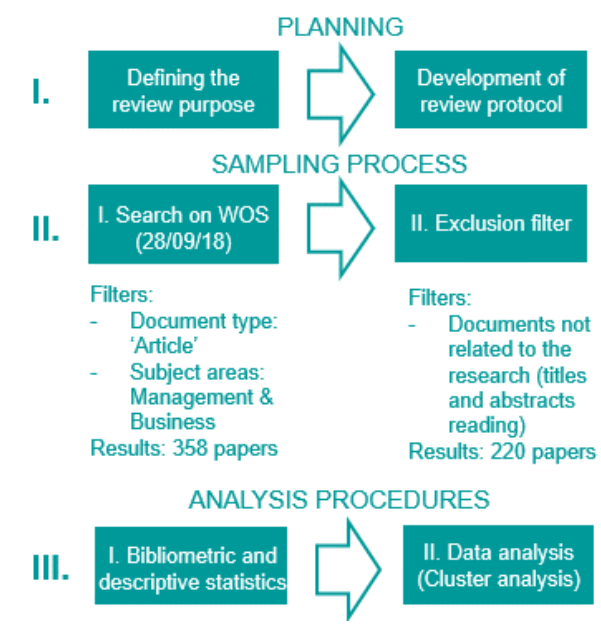

Figure 1. Summary of the systematic review process

\section{Planning the SLR}

During the planning phase, we determined the purposes of the research and its most important aspects. Our main goal was to identify how past research employed $A C$ in an entrepreneurship and startups context. We did not limit the research to any specific time frame and only peer-reviewed articles were included. We conducted a search in September 2018 on the Web of Science (WOS, Clarivate Analytics) database since it is one of the most complete peer- 
review journal repositories on social sciences (Crossan \& Apaydin, 2010). We defined two subject areas, "Management" and "Business," and searched in all the indexes provided on WOS (SCl-EXPANDED, SSCl, A\&HCl, CPCl-S, $\mathrm{CPCl}-\mathrm{SSH}$, and $\mathrm{ESCl})$. Given the wide diversity of terms and morphological variety to refer to a "recently created innovative company", we applied the following Boolean search keywords: "((absorptive capacity) AND ("startup" OR "start-up" OR "start up" OR "new firm*" OR "NTBF" OR "new venture" OR "entrepreneur*")) in the Topic (title, keywords or abstract) category.

\section{Sampling process}

The search returned 358 papers. An exclusion filter was applied to select only documents that address AC in the context of entrepreneurship, on the basis of a thorough reading of titles and abstracts. In order to minimize bias in this filter parameter, the documents were reviewed in two rounds by the researchers. The final search process yielded 220 documents published between 2001 and 2018.

\section{Data analysis}

We performed bibliometric and statistical analyses to provide an overview of the literature, including the publications per year and the main journals. We also carried out a network analysis employing the VOSviewer 1.6.9 Software. The data was extracted directly from WOS, including all the information items (e.g., title, abstract, keywords, publication year, cited references, etc.). Then, we manually removed the non-related documents using Microsoft Excel. These data were exported to a text file $\left({ }^{*} \mathrm{txt}\right)$ and imported to VOSviewer to create the co-occurrence and co-citation networks in order to identify the main theoretical references and central discussions. We used the default settings of the program, as presented in Table 1.

Table 1. Default settings of VOSviewer

\begin{tabular}{ll}
\hline Parameter & Default settings \\
\hline Counting method & Full counting \\
Method of normalization & Association strength \\
Layout of attraction repulsion & 2 \\
Layout of repulsion & 0 \\
Clustering resolution & 1.00 \\
Minimum size of clusters & 1 \\
Merging small clusters & Switched on \\
\hline
\end{tabular}


Based on the all keywords co-occurrence network, we identified three clusters of lines of research: knowledge, innovation, and performance. Afterward, we proceeded to classify all the papers of our database into these three clusters using Microsoft Excel. After reading the documents, we selected the most relevant articles that matched the research goal and the clustering parameter as well. A total of 50 papers satisfied these parameters and are discussed in the content analysis. The documents were manually coded using the Mendeley Desktop 1.19 software and Microsoft Excel, considering the following aspects: 1) Authors, 2) Year of publication, 3) Journal, 4) Type of article, 5) Aim of research, 6) Relevance of absorptive capacity, 7) Methodology, sample, and variables, 8) Findings, and 9) Future research agenda. We provide a detailed explanation of the coding process in Appendix A (Knowledge cluster; Innovation cluster; Performance cluster.)

\section{RESULTS}

\section{Bibliometric and descriptive analyses}

Figure 2 shows the evolution of publications over time. It is observed that the earliest paper in the sample was published in 2001; from 2009, there is an increase in the number of publications, reaching a peak in 2015 with 26 publications. The 220 articles are distributed over 77 journals. Table 2 shows the most representative journals accounting for about 60 percent of the sample.

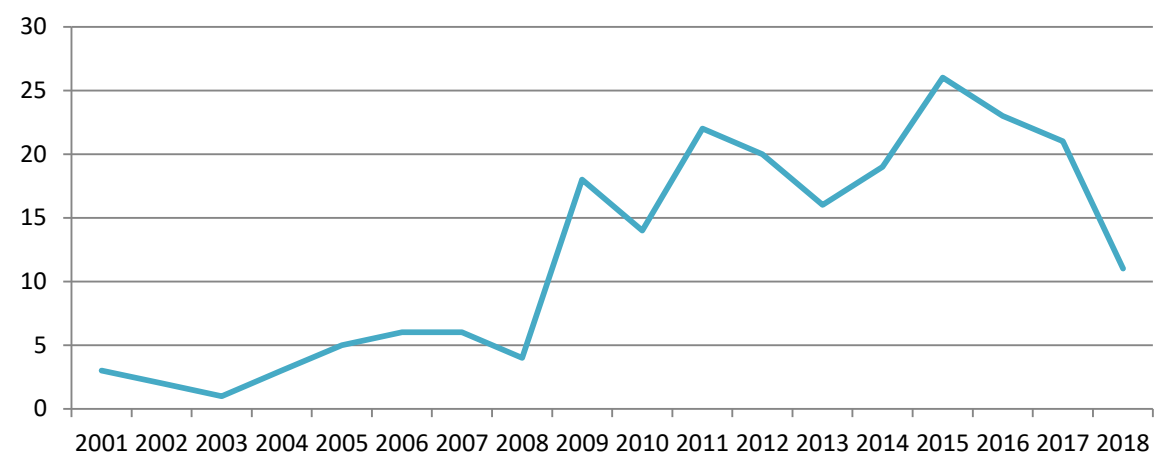

Figure 2. Number of papers published on AC and Startups over time 
Table 2. Most common outlet journals

\begin{tabular}{llc}
\hline Abbreviation & Full Title & Articles \\
\hline JBV & JOURNAL OF BUSINESS VENTURING & 16 \\
SEJ & STRATEGIC ENTREPRENEURSHIP JOURNAL & 12 \\
ET\&P & ENTREPRENEURSHIP THEORY AND PRACTICE & 11 \\
JSBM & JOURNAL OF SMALL BUSINESS MANAGEMENT & 11 \\
IBR & INTERNATIONAL BUSINESS REVIEW & 10 \\
RP & RESEARCH POLICY & 10 \\
SBE & SMALL BUSINESS ECONOMICS & 9 \\
ERD & ENTREPRENEURSHIP AND REGIONAL DEVELOPMENT & 7 \\
JWB & JOURNAL OF WORLD BUSINESS & 7 \\
JTT & JOURNAL OF TECHNOLOGY TRANSFER & 6 \\
R\&DMANAGEE & R \& D MANAGEMENT & 6 \\
SMJ & STRATEGIC MANAGEMENT JOURNAL & 6 \\
IJTM & INTERNATIONAL JOURNAL OF TECHNOLOGY & 5 \\
JMS & MANAGEMENT & \\
EMJ & JOURNAL OF MANAGEMENT STUDIES & 5 \\
IMM & EUROPEAN MANAGEMENT JOURNAL & 4 \\
ISBJ & INDUSTRIAL MARKETING MANAGEMENT & 4 \\
& INTERNATIONAL SMALL BUSINESS JOURNAL & 4 \\
\hline
\end{tabular}

In order to identify the central authors, we performed a co-citation analysis based on cited authors. This analysis builds a network based on the citation link (where one item cites the other). We set this parameter to a minimum of " 40 citations of an author," resulting in 41 central authors, as seen in Figure 3.

The map shows the number of citation links (represented by the number of lines) and the link strength (represented by the distance between items), which refers to a similarity measure normalized by the association strength (van Eck \& Waltman, 2010). Zahra S. is the author with the most citation links (412) and total link strength (6082) followed by Cohen W. with 233 and 3067 , respectively. The number of links and total link strength of the central authors is displayed in Table 3. 


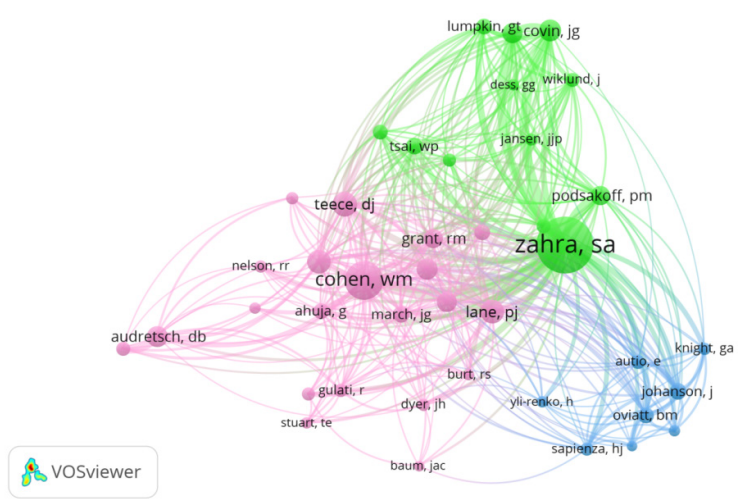

Figure 3. Co-citation author network

Table 3. Citation link and link strength of the co-citation author network

\begin{tabular}{llllll}
\hline Author & Citation link & Link strength & Author & Citation link & Link strength \\
\hline Acs Z. & 58 & 841 & Kogut B. & 97 & 1653 \\
Ahuja G. & 67 & 1103 & Lane P. & 121 & 1879 \\
Audretsch D. & 101 & 1290 & Lumpkin G. & 66 & 1261 \\
Autio E. & 56 & 1100 & March J. & 72 & 1214 \\
Barney J. & 54 & 874 & McDougall P. & 44 & 827 \\
Baum J. & 40 & 605 & Miller D. & 95 & 1747 \\
Burt R. & 44 & 823 & Nelson R. & 47 & 727 \\
Chesbrough & 41 & 500 & Nonaka I. & 69 & 1097 \\
Cohen W. & 233 & 3067 & Oviatt B. & 69 & 1366 \\
Coviello N. & 40 & 829 & Podsakoff P. & 87 & 1537 \\
Covin J. & 105 & 2012 & Rothaermel F. & 51 & 709 \\
Dess G. & 42 & 771 & Sapienza H. & 53 & 984 \\
Dyer J. & 48 & 947 & Shane S. & 116 & 1694 \\
Eisenhardt K. & 99 & 1487 & Shumpeter J. & 46 & 728 \\
Grant R. & 86 & 1469 & Stuart T. & 42 & 603 \\
Gulati R. & 51 & 975 & Teece D. & 123 & 1888 \\
Helfat C. & 61 & 995 & Tsai W. & 72 & 1278 \\
Hitt M. & 58 & 1015 & Wiklund J. & 58 & 1208 \\
Jansen J. & 49 & 887 & Yli-renko H. & 41 & 814 \\
Johanson J. & 74 & 1444 & Zahra S. & 412 & 6082 \\
Knight G. & 47 & 914 & & & \\
\hline & & & & & \\
\hline & 49 & & & 42 \\
\hline
\end{tabular}




\section{Top 10 Co-citation references network}

We also built another co-citation network but based on the analysis of cited references to find commonalities in the theoretical background. The resultant network, exhibited in Figure 4, contains the top ten cited references. We present a brief description of these publications below.

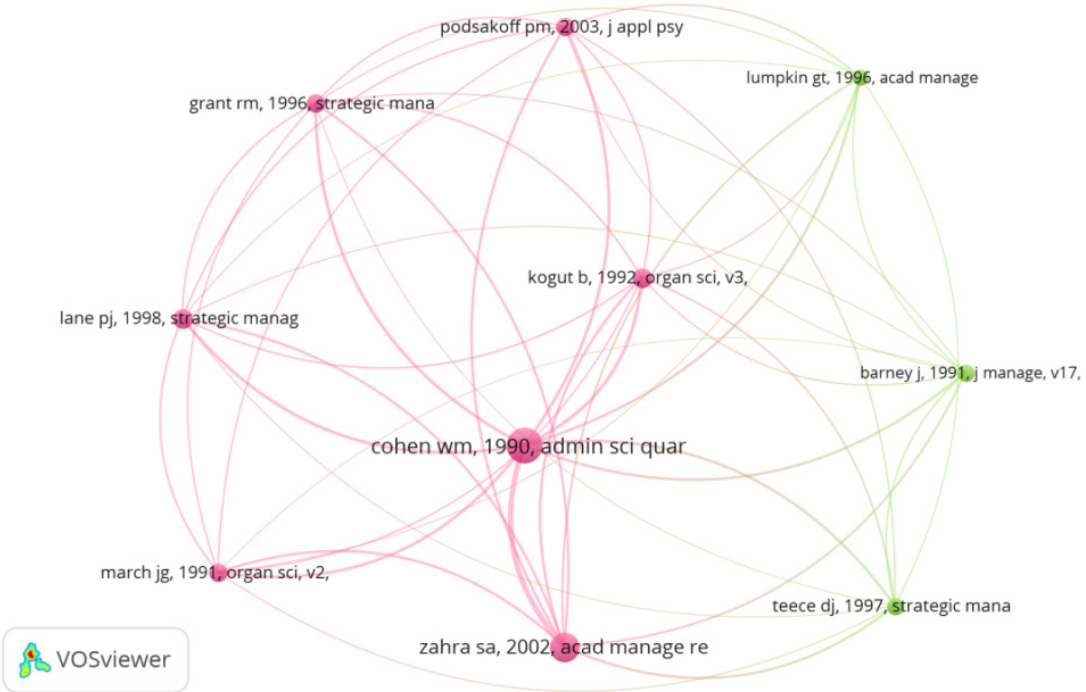

Figure 4. Top 10 Co-citation references network

Cohen and Levinthal (1990, p. 128) introduced the term AC to refer to the "ability of a firm to recognize the value of new, external information, assimilate it, and apply it to commercial ends." The authors argue that AC is critical to the firms' innovative capabilities, and it requires prior related knowledge to evaluate and utilize the outside new knowledge. Similarly, March (1991, p. 83) suggested that knowledge "makes performance more reliable," and learning and technological changes might improve competitive advantage. In this study, March popularized the idea that firms must enhance their technological explorative and exploitative abilities and look for a balance between them in order to ensure survival and achieve better performance. In this regard, Barney (1991), aiming for a more comprehensive understanding of sustained competitive advantage, proposed that some resources and characteristics (such as heterogeneity, valuable, rareness, or inimitableness) are crucial for a firm's competitiveness, and they may vary over time. 
To Kogut and Zander (1992), one central aspect of the competitive dimension is the ability to transfer knowledge within the firm. The authors drew on the perspective that organizations are repositories of tacit and explicit knowledge, skills, and social networks, which enable companies to learn new abilities by recombining their existent resources and capabilities. In this same vein, Grant (1996) explores how to integrate the specialized knowledge of individuals into firms. Drawing on the resource-based theory, Grant (1996, p. 110) conceptualizes the knowledge-based view as a new perspective to understand a company, placing knowledge as "the most strategically important of the firm's resources." Additionally, he identified the key characteristics of knowledge in order to create value: transferability (the capacity of transference across individuals), capacity of aggregation (the potential to add new knowledge to the existing one), and appropriability (the ability of the owner of a resource to receive a return).

Alternatively, Lumpkin and Dess (1996) explore the relationship between entrepreneurial orientation (EO) and firm performance. The authors defined EO as the practices, processes, and decision-making activities that lead the firm to enter new or existing markets, and is characterized by the "propensity to act autonomously, a willingness to innovate and take risks, and a tendency to be aggressive toward competitors and proactive relative to marketplace opportunities" (Lumpkin \& Dess, 1996, p. 137).

In order to address the question of how firms achieve sustained competitive advantage, Teece et al. (1997) proposed the dynamic capabilities concept. As discussed in section 2, this perspective "emphasizes the development of management capabilities, and difficult-to-imitate combinations of organizational, functional and technological skills" (Teece et al., 1997, p. 510). Similarly, from the basis that not all firms have equal chances to acquire knowledge, Lane and Lubatkin (1998) reconceptualized the construct of $A C$ as a dyad-level construct and established some conditions for this interaction to occur: the specific type of knowledge, similarities in practices, logic and organizational structure, and familiarities between the firms. Zahra and George (2002) also reconceptualized AC as a dynamic capability related to knowledge creation and exploitation in order to gain sustained competitive advantage. Additionally, they proposed that $A C$ is built upon two capacities: potential capacity (knowledge acquisition) and realized capacity (knowledge transformation and exploitation). Ending this top ten references network, Podsakoff et al. (2003) present an important methodological review about biases in behavioral research methods that are often employed and cited by AC researchers. The authors summarized the most common sources of method biases, their effects, and techniques to control them. 


\section{Content analysis}

Finally, we created the co-occurrence map using all keywords as the unit of analysis, as presented in Figure 5 . We used the default parameter of a minimum of 10 occurrences of a keyword (Eck \& Waltman, 2018). According to Gomes et al. (2016), keywords maps are widely used by researchers and help to establish a general idea on a certain subject. From this map, three clusters of lines of research addressing AC in startups were identified: knowledge (26 articles), innovation (11 articles), and performance (13 articles). Based on these clusters, we performed our data analysis and identified the following codes: 1) Authors, 2) Year of publication, 3) Journal, 4) Type of article, 5) Aim of research, 6) Relevance of absorptive capacity, 7) Methodology, sample, and variables, 8) Findings, and 9) Future research agenda.

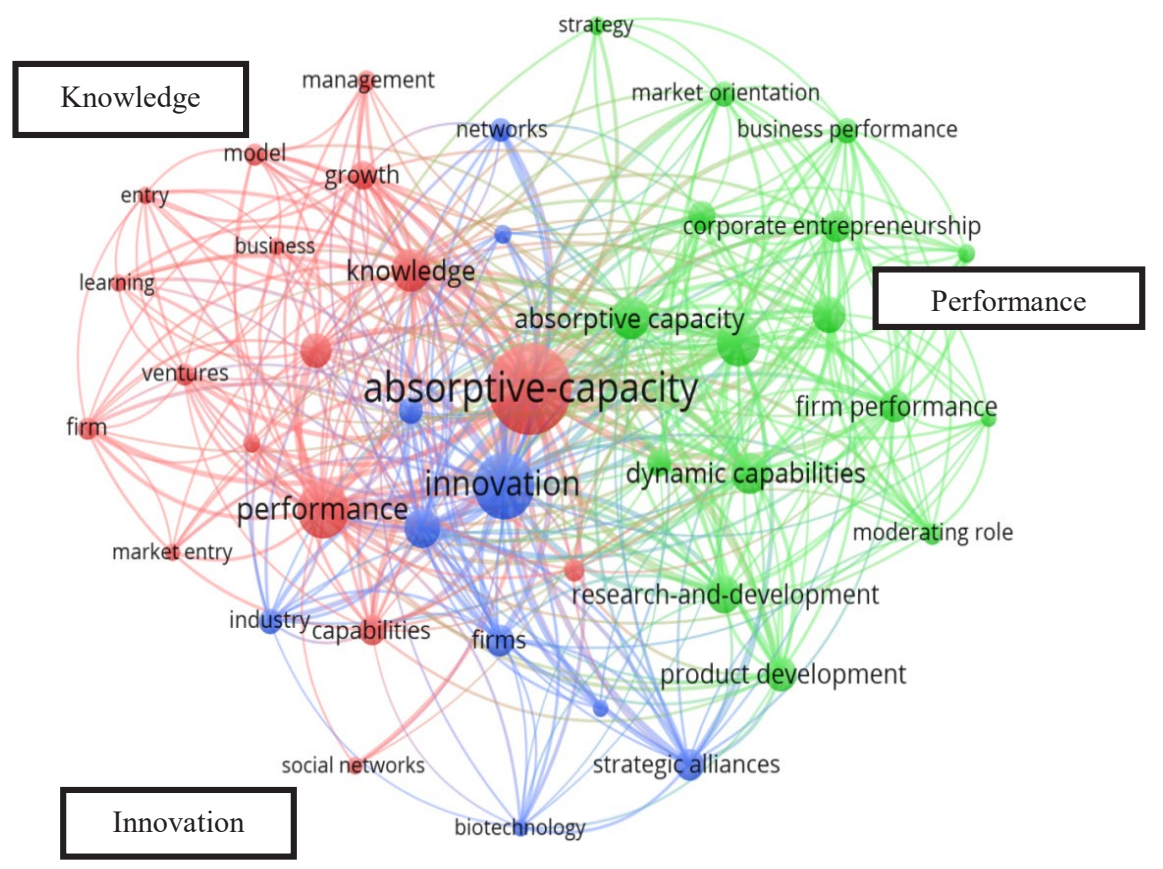

Figure 5. Co-occurrence map using all keywords 


\section{Knowledge cluster}

New knowledge is an essential input factor for innovation and new firm's progress (Mueller, 2006; Prashantham \& Young, 2011; Sullivan \& Marvel, 2011; McKelvie, Wiklund, \& Brattström, 2018; Bingham \& Davis, 2012) by offering the possibility of renewing existent skills, technological paths, and developing innovative capabilities to improve competitive advantage and stimulate growth (Zahra, Filatotchev, \& Wright, 2009; Agarwal, Audretsch, \& Sarkar, 2010). Several authors recognize R\&D as a major vehicle to acquire new knowledge (Acs, Braunerhjelm, Audretsch, \& Carlsson, 2009; Mueller, 2006). However, very often, new and small firms do not have the resources to structure an R\&D department; thus, partnerships with institutions such as universities or research laboratories are crucial to develop new knowledge (Hayton \& Zahra, 2005; Hayter, 2013; Carayannis, Provance, \& Grigoroudis, 2016; Dai, Goodale, Byun, \& Ding, 2018). Sullivan and Marvel (2011) emphasize that technology and market knowledge is highly important to achieve positive results and enhance the innovative process. In any case, direct inter-personal contacts and proximity to the environment are useful to access knowledge (including tacit knowledge) faster and more successfully (Mueller, 2007, p. 356).

Based on Huber (1991), De Clercq et al. (2012) categorized knowledge acquisition (KA) into five types: experiential learning (learning from experience), vicarious learning (learning by observing others), searching (learning by searching for specific information), grafting (learning by incorporating entities that possess knowledge), and congenital learning (drawing on intrinsic knowledge gained from founders or personal experience). Differently, Carayannis, Provance, and Givens (2011) proposed to classify KA into two groups regarding the form of acquisition: (1) formal KA and arbitrage (referring to the intended ability to manage and apply knowledge for a specific purpose), and (2) informal KA and serendipity (referring to the unintended rewards of enabling knowledge from different sources).

Friesl (2012) identified four knowledge acquisition strategies: "low key" in which there are low levels of collaborative and internal learning and low performance as well; "mid-range," where the emphasis is on collaborative and market-based learning but low levels of internal learning; "focus," where the firms' efforts concentrate on both collaborative and internal learning; and "explorer," in which firms have high mean values for all knowledge acquisition categories (i.e., collaborative, internal, and market-based learning). In this latter group, firms have a particular interest in renewing their knowledge base in order to achieve the highest level of performance.

We identified three recurrent research topics in the present cluster: entrepreneurial internationalization (EI), spin-offs, and identification of 
opportunities. The first topic, El, explores how new firms go about looking to expanding their activities into foreign markets (De Clercq et al., 2012; Bruneel, Yli-Renko, \& Clarysse, 2010; Yu, Gilbert, \& Oviatt, 2011). Considering that entering foreign markets might entail the obsolescence of existing knowledge and capabilities, to acquire new knowledge becomes crucial to successful internationalization (De Clercq et al., 2012; Prashantham \& Young, 2011; Bruneel et al., 2010; Fernhaber, McDougall-Covin, \& Shepherd, 2009; Tolstoy, 2009). Therefore, AC emerges as a cornerstone for new venture survival and a critical factor for growth (Mueller, 2007; Qian \& Acs, 2013; Moon, 2011). Some studies point out that networks and alliances may enable and accelerate initial commercial activities in new markets (Bruneel et al., 2010; Yu et al., 2011; Sullivan \& Marvel, 2011; Perez, Whitelock, \& Florin, 2013), and support the absence of in-house translators of new knowledge as suggested in AC theory (Cohen \& Levinthal, 1990).

The second topic of research studies is the creation of spin-offs as a vehicle to commercialize new knowledge developed in public research institutes, in large incumbent firms, or in universities (Knockaert, Ucbasaran, Wright, \& Clarysse, 2011; Qian \& Acs, 2013; Hayter, 2013; Patton, 2014). Qian and Acs (2013, p. 191) argued that the level of knowledge spillover entrepreneurship depends not only on the speed or level of knowledge creation, but also on entrepreneurial absorptive capacity (EAC), defined as the "ability of an entrepreneur to understand new knowledge, recognize its value, and subsequently commercialize it by creating a firm." Different from Cohen and Levinthal's AC concept, EAC focuses on the entrepreneur's abilities -not on the firm's abilities- and involves the capacity to build a new business.

The third and last topic considers AC as a means to identify opportunities and enhance the firm's performance (McKelvie et al., 2018; Saemundsson \& Candi, 2017). Due to the fact that existing knowledge base might become obsolete within a short period of time, new ventures must intensively promote the search for novel knowledge, primarily in market and customer knowledge (McKelvie et al., 2018). Regarding the principles of AC set by Cohen and Levinthal (1990), to absorb new knowledge requires certain existent abilities. This is probably a challenge for startups because, in many cases, they are building new markets and customers have not been identified at all. In this respect, McKelvie et al. (2018) suggest that new ventures may not overrely on external knowledge acquisition, especially when the firm works in a highly dynamic sector. Furthermore, Saemundsson and Candi $(2017$, p. 43) proposed to divide potential AC into "problem absorptive capacity, i.e. the ability to identify and acquire knowledge of the goals, aspirations and needs of current and potential customers, and solution absorptive capacity, i.e. the ability to identify and acquire external knowledge of solutions to fulfill 
them." The authors found out that changes in problem absorptive capacity are a stronger trigger for identification of new opportunities than changes in solution absorptive capacity.

\section{Innovation cluster}

According to Dushnitsky and Lenox (2005a, 2005b), Corporate Venture Capital (CVC) carry a potential innovative benefit. The authors suggest that the greater the firm's AC, the greater the firm's investment in entrepreneurial new ventures and, therefore, the firm's innovation rate (Dushnitsky \& Lenox, $2005 b, 2005 a)$. Nevertheless, the role of AC is not restricted to an enabler of innovation. In fact, access to new information provided by CVC can improve the AC of the firms (Wadhwa \& Hall, 2005), although this strategy may limit the knowledge created. Similarly, Lee, Kim, and Jang (2015) argue that the firm's knowledge diversity enables corporate investors to acquire and maximize useful knowledge.

On the other hand, Winkelbach and Walter (2015) found out that prior knowledge held by the firms has a non-significant effect on value creation. Knowledge creation and knowledge-related learning capabilities (which are moderated by $\mathrm{AC}$ ) enable firms to deal with dynamic environments to create value and develop innovation. Scholars approach the pursuit of new knowledge by firms to promote innovation in different ways. For instance, human mobility across national borders may foster knowledge creation (Liu, Wright, Filatotchev, Dai, \& Lu, 2010). The new knowledge may come from scientists and engineers that return from abroad to start up a new venture in their native countries (Liu et al., 2010). Regarding the type of source of new knowledge (i.e., internal or external), Kamuriwo, Baden-Fuller, and Zhang (2017) point out that external knowledge development is more associated with breakthrough innovations and with a faster time-to-market.

Nevertheless, existing literature suggests that there are some setbacks related to knowledge acquisition and innovation. Marvel (2012) pointed out that sometimes knowing less is better to create innovation. His findings suggest that acquiring the knowledge of ways to serve markets is "negatively associated with innovation radicalness" (Marvel, 2012, p. 464). Therefore, the less knowledge about existing offerings in the market and how they work, the greater the chances for developing breakthrough innovations.

Knowledge acquisition can also stem from universities in the form of academic entrepreneurship, technology transfer, and research commercialization. Using the AC perspective, two multiple case studies explored the Proof of Concept ( $\mathrm{PoC}$ ) process within a University Science Park Incubator (UK) and provided evidence that AC plays a crucial role in obtaining 
commercial outcomes (McAdam, McAdam, Galbraith, \& Miller, 2010; McAdam, McAdam, \& Brown, 2009).

Finally, network market orientation is found to make a significant contribution to the development of $\mathrm{AC}$ in international new ventures. Monferrer, Blesa, and Ripollés (2015) showed that network market orientation facilitates the development of dynamic adaptive and absorptive capabilities, which influence their capacity to develop innovative, dynamic capabilities.

\section{Performance cluster}

AC might also moderate the firm's performance (Nielsen, 2015; Zahra \& Hayton, 2008). In our review, we found two perspectives of performance: addressed as a capability to innovate and as a financial output. Typically, firms engage in activities such as acquisitions, alliances and CVC when pursuing growth and profitability. Yet, it is not completely clear how these activities may influence the firm's performance. To that end, Zahra and Hayton (2008) suggest that AC moderates this relationship. According to their findings, after studying 217 global manufacturing firms, the investments made for building AC positively influence the firm's performance benefits derived from international venturing. Conversely, Benson and Ziedonis (2009, p. 330) argue that "internal technological capabilities remain a critical determinant of success in innovation-driven acquisitions." A limit on CVC investment is imposed by the acquirer's total R\&D expenditures, and beyond this limit, the firm's performance starts to improve at a diminishing rate. Wales, Parida, and Patel (2013) posit that the relationship between AC and financial performance is mediated by Entrepreneurial Orientation (EO) referred to as the "strategymaking practices, management philosophies, and firm-level behaviors that are entrepreneurial in nature" (Anderson, Covin, \& Slevin, 2009. p. 220).

Based on an individual perspective of AC, Nielsen (2015) proposes that individuals with higher levels of education have also higher absorptive and learning capacities that leverage the likelihood of firms' survival and growth. Additionally, some authors (for instance, Rhee, 2008; Witt, 2004) claim that, in general, the social network represents the theoretical lenses used to investigate performance and startup success. Surprisingly, Rhee (2008) found that social networks of the startup's team members do not help their ventures to reap superior performance. By comparing university and corporate spin-offs, Clarysse, Wright, and Van de Velde (2011) revealed that different characteristics in the technological knowledge base (e.g., specificity, newness, or tacitness) influence the spin-off's performance and growth. According to Simsek and Heavey (2011), corporate entrepreneurship impacts positively the knowledge- 
based human, social, and organizational capital and is also positively associated with the firm's performance (i.e., profitability and growth).

Considering international sales performance, Javalgi, Hall, and Cavusgil (2014) argue that AC has a positive relation with customer-oriented selling and performance in international B2B settings. Furthermore, Un and MontoroSanchez (2011) define performance as the development of new technological capabilities through investments in R\&D. Their research uncovered that the prior capabilities enable the firm to develop new technological ones. In another approach, Zheng, Liu, and George (2010) suggest that a key performance indicator is the valuation or market value, which is influenced by the innovative capability and the network heterogeneity of the firms.

Dynamic and operating capabilities must interact to enable entrepreneurship (Newey \& Zahra, 2009). AC may be a key knowledgebased mechanism, which connects learning at both product development and portfolio planning levels. Finally, Deeds (2001) suggests that there is a positive relationship between a high technology venture's R\&D intensity, technical capabilities, and $A C$ and the amount of entrepreneurial wealth created by the venture.

\section{DISCUSSION}

On the basis of the issues raised in the previous section, we observed a relationship between the three clusters: firms employ and develop their AC in order to identify and transform new knowledge into innovation projects, which in turn leads to performance improvement and growth (see figure 6). This relationship is confirmed by authors such as Mueller (2006), who emphasizes the contribution of new knowledge and knowledge exploitation as valuable inputs for economic regional growth. Moreover, Zahra et al. (2009) reinforce the idea that for a startup to grow, it is necessary to revamp its skills, replace its dated capabilities, and build up new ones. In this regard, AC plays an important role as an enabler for integrating knowledge from different sources. Another approach that supports the relationship presented in Figure 6 is the innovation capability because this construct integrates the creation or appropriation of new knowledge, the transformation of that knowledge into new or improved products, and the firm's progress or performance enhancement (Aas \& Breunig, 2017). 


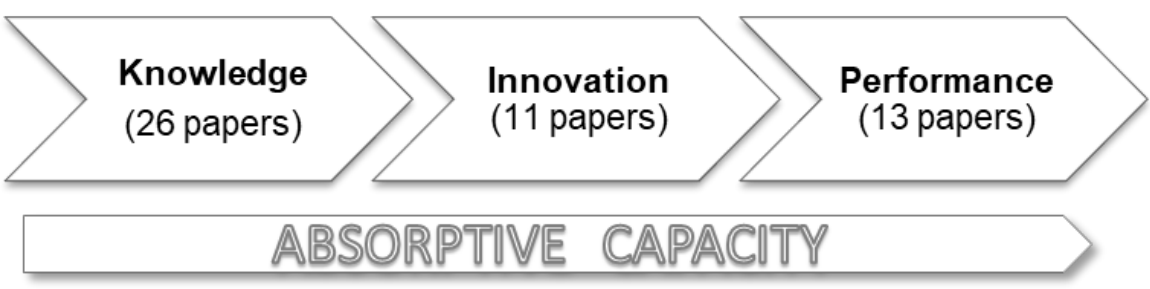

Figure 6. Relationship between the three clusters

We identify that there are open discussions about different aspects. The first is the favorability of certain types of knowledge sources (i.e., internal or external) for developing innovations. McKelvie et al. (2018) argue that in highly dynamic environments, the payoff attributed to investments in externally acquired knowledge is not significant. In this same vein, Marvel (2012) found out that knowing less is better to create innovation; the less knowledge about existing offerings in the market, the greater the chances for developing breakthrough innovations. Conversely, Kamuriwo et al. (2017) claim that external knowledge development is more associated with breakthrough innovations and with a faster time-to-market. The second aspect is the role of prior knowledge. On the one hand, Winkelbach and Walter (2015) identify the sole reliance on prior knowledge may foster traps and hinder the ability to foresee opportunities. On the other hand, Un and Montoro-Sanchez (2011) argue that prior stock of knowledge and capabilities enable the development of new ones and thus ensure value creation. Finally, there are some mismatches related to the volume of new knowledge required for developing breakthrough innovations; in the discussion set out by Marvel (2012) it is not clear whether large amounts of knowledge are favorable or not in the development of radical innovation products.

There are three major reasons for companies to engage in knowledge renewal: to address the evolving character of environmental conditions and customer's preferences for enabling growth (Marvel, 2012; Perez et al., 2013; Zahra et al., 2009), to enter into foreign markets (i.e., internationalization) (Prashantham \& Young, 2011; Rhee, 2008; Tolstoy, 2009), and to identify entrepreneurial opportunities (McKelvie et al., 2018; Saemundsson \& Candi, 2017). Regarding the types of strategies for knowledge acquisition, we identified two of the former: formal and informal (Carayannis et al., 2011), and two of the latter: internal and external (Friesl, 2012) (see Figure 7). 
Types of strategies for acquiring knowledge

\begin{tabular}{|c|c|c|}
\hline & Internal & External \\
\hline Formal & $\begin{array}{ll}\text { - } & \text { Experiential } \\
\text { - } & \text { Vicarious } \\
\text { - } & \text { Searching } \\
\text { - } & \text { Congenital }\end{array}$ & $\begin{array}{ll}\text { - } & \text { Grafting } \\
\text { - } & \text { Human mobility } \\
\text { - } & \text { Partnerships } \\
& \text { with universities } \\
& \text { and institutions } \\
\text { - } & \text { Social networks } \\
\text { - } & \text { Acquisitions and } \\
& \text { alliances }\end{array}$ \\
\hline Informal & $\begin{array}{l}\text { Serendipity } \\
\text { (unintended } \\
\text { process) }\end{array}$ & $\begin{array}{c}\text { Serendipity } \\
\text { (unintended } \\
\text { process) }\end{array}$ \\
\hline
\end{tabular}

Figure 7. Types and strategies of knowledge acquisition

Internal-formal strategies comprise four categories: experiential learning (learning from experience), vicarious learning (learning by observing others, for instance, customers or competitors), searching (learning by searching for specific information), and congenital learning (drawing on intrinsic knowledge gained from founders or personal experience) (De Clercq et al., 2012). On the other hand, external-formal strategies include grafting (learning by incorporating entities that possess knowledge) (De Clercq et al., 2012), human mobility (i.e., knowledge transfer from the exchange of experience as a result of human mobility across national borders) (Liu et al., 2010), partnerships with universities and technology institutions (Clarysse et al., 2011; Mueller, 2006), social networks (Newey \& Zahra, 2009; Witt, 2004), and acquisitions and alliances (Dai et al., 2018; Yu et al., 2011; Zahra $\&$ Hayton, 2008). Both internal-informal and external-informal are based on the serendipity approach, which refers to the unintended rewards of enabling knowledge from different sources (Carayannis et al., 2011).

From the review, we highlight three recommendations for startups concerning absorptive capacity. First, considering the resource limitations of startups, developing partnerships with institutions such as universities or research laboratories could enhance the capacity for identifying and gathering new knowledge (Hayton \& Zahra, 2005; Hayter, 2013). Second, networking, direct inter-personal contacts, and proximity to the environment are useful to access knowledge and become crucial to successful internationalization (De Clercq et al., 2012; Mueller, 2007). Finally, in order to improve the opportunities recognition, new firms should emphasize the problem 
absorptive capacity, in other words, in identifying and acquiring knowledge related to the aspirations and needs of current and potential customers, instead of on existent solutions (Saemundsson and Candi, 2017)

Additionally, some common issues among researchers were identified. First, there is wide adoption of the definition of AC proposed by Cohen and Levinthal (1990) as the mechanism through which firms identify, acquire, and exploit new knowledge in order to achieve more sustainable levels of growth. Second, internal capabilities enable the firm to transform new knowledge into value. Third, intellectual property rights may inhibit the openness to acquire external knowledge and limit the offers to receive venture capital.

\section{CONCLUSION AND FUTURE RESEARCH AGENDA}

The purpose of this paper was to identify how the concept of $A C$ has been addressed in the new venture context. We selected 220 documents and applied a systematic literature review method that evidenced three clusters of research: knowledge, innovation, and performance. We concluded that the AC construct first conceived by Cohen and Levinthal in 1990 still stands as an important theoretical lens. Several scholars used the concept in its original context, but others extended it to other research fields, such as the role of $A C$ in universities and research institute spin-offs, corporate venture capital, entrepreneurs' networks, and as a crucial factor to new venture performance.

Bibliometric analyses showed an increasing interest in $\mathrm{AC}$ in the context of new firms. In spite of the earliest paper being published in 2001, the main concepts (which currently prevail) were proposed during the decades of the 1990s (Cohen \& Levinthal, 1990; Grant, 1996; Kogut \& Zander, 1992; Lumpkin \& Dess, 1996) and the early 2000s (Zahra \& George, 2002). We identify three inter-related clusters of research regarding the importance of $A C$ in the new venture context: knowledge, innovation, and performance. The relationship between the clusters reflects how firms employ and develop their AC in order to identify and transform new knowledge into innovation projects, which in turn leads to performance improvement and growth.

Content analysis revealed three main concerns related to knowledge obsolescence: growth and dynamic environment and markets, entrepreneurial opportunities, and internationalization. Firms can apply several strategies, internal or external, in order to acquire knowledge, and also might follow both formal and informal processes to address the strategies.

Regarding future research, we identify three avenues exhibit in Table 4. The first avenue contemplates $\mathrm{AC}$ from the individual perspective to follow the multilevel approach set by some management areas, which started with 
the firm level, business unity, project, and ended on an individual level (e.g., uncertainty management; Gomes et al., 2019). The second avenue centers on bibliometric analysis and literature reviews aiming to identify pivotal studies, which have changed or incorporated content into the AC literature. Finally, the third avenue is related to the strategies for knowledge acquisition in order to clarify the conflicting aspects identified in our content analysis.

Table 4. New avenues for future research

\begin{tabular}{|c|c|}
\hline Avenues for future research & Potential research questions \\
\hline The individual perspective & $\begin{array}{l}\text { - Which are the micro-foundations and individual } \\
\text { cognitive aspects associated with AC and knowledge } \\
\text { renewal? } \\
\text { - Which mechanisms can contribute to the enhancement } \\
\text { of AC? For instance: } \\
\text { - Exposure to new experiences } \\
\text { - Involvement with different areas of knowledge } \\
\text { - Access to education and training programs }\end{array}$ \\
\hline $\begin{array}{l}\text { Bibliometric analysis and } \\
\text { literature review }\end{array}$ & $\begin{array}{l}\text { - How has the AC concept evolved, and which are the } \\
\text { pivotal studies that have changed or incorporated } \\
\text { content to the AC literature? }\end{array}$ \\
\hline Strategies for $\mathrm{KA}$ & $\begin{array}{l}\text { - Which are the barriers and constraints for KA during the } \\
\text { different stages of the startup formation? } \\
\text { - What is the effect of the type of strategy for KA } \\
\text { (internal or external) on the degree of radicalness of the } \\
\text { innovations of the startups? } \\
\text { - What is the relationship between the type of strategy } \\
\text { for KA and the appropriateness for determining the } \\
\text { problem (customer concerns) or the solution (product } \\
\text { concerns)? }\end{array}$ \\
\hline
\end{tabular}

In addition, we identify some suggestions from the literature: empirical research for validating models or propositions, considering larger samples, longitudinal analysis, different sectors, cultures, and regions. Furthermore, the authors propose to conduct further studies analyzing the types of networks, the interdependencies between the innovation strategies, public policy on innovation, and incorporating different measures of AC.

We contribute to the innovation and entrepreneurship literature in different ways. First, we have connected the importance of $A C$ and new venture creation, to provide a better understanding of how entrepreneurs could enhance their innovative processes. Second, we have established an overview of the existing literature on AC in startups, highlighting the main authors and drivers. Third, we have clustered the pertinent literature with distinct research themes regarding the entrepreneurial AC found in our systematic review and have also proposed a framework that differentiates 
knowledge acquisition strategies for new ventures. Finally, we have suggested future research opportunities on entrepreneurship and absorptive capacity.

The results also allow us to identify some practical implications. The analyzed literature suggests that there are certain strategies that entrepreneurs may adopt in order to acquire and absorb new knowledge. We categorize these strategies according to the knowledge source (i.e., internal or external) and the degree of intentionality (i.e., formal or informal). This effort is aimed at persuading entrepreneurs and practitioners to bear in mind a wide range of strategies that mediate between acquiring knowledge and achieving growth objectives and expansion into new markets.

Finally, some limitations must be considered regarding the systematic literature review method. First, concerning the sampling procedures, the keyword selection, which includes only articles published in English and databases from one specific scientific citation indexing service, can limit the resulting sample. In addition, there is some subjectivity involved in the selection of articles for analysis; this is mainly because it relies on the authors' interpretations from reading titles and abstracts. Furthermore, the concept of startups is not very precise. We noticed that it still remains ambiguous and unclear since it is defined differently among the authors. Therefore, it can be difficult to filter the sample in order to restrict the analyses to one specific type of firm.

\section{Acknowledgment}

This work was supported in part by Coordination for the Improvement of Higher Education Personnel (CAPES) Foundation (a Brazilian research agency) under scholarship grants.

\section{References}

Aas, T. H., \& Breunig, K. J. (2017). Conceptualizing innovation capabilities: A contingency perspective. Journal of Entrepreneurship, Management and Innovation, 13(1), 7-24. https://doi.org/10.7341/20171311

Acs, Z. J., Braunerhjelm, P., Audretsch, D. B., \& Carlsson, B. (2009). The knowledge spillover theory of entrepreneurship. Small Business Economics, 32(1), 15-30. https://doi.org/10.1007/s11187-008-9157-3

Agarwal, R., Audretsch, D., \& Sarkar, M. (2010). Knowledge spillovers and strategic entrepreneurship. Strategic Entrepreneurship Journal, 4(4), 271-283. https://doi.org/10.1002/sej.96

Ambos, T. C., \& Birkinshaw, J. (2010). How do new ventures evolve? An inductive study of archetype changes in science-based ventures. 
Organization Science, 21(6), 1125-1140. https://doi.org/10.1287/ orsc.1090.0504

Anderson, B. S., Covin, J. G., \& Slevin, D. P. (2009). Understanding the relationship between entrepreneurial orientation and strategic learning capability: An empirical investigation. Strategic Entrepreneurship Journal, 3(3), 218-240. https://doi.org/10.1002/sej

Apriliyanti, I. D., \& Alon, I. (2017). Bibliometric analysis of absorptive capacity. International Business Review, 26(5), 896-907. https://doi. org/10.1016/j.ibusrev.2017.02.007

Arend, R. J. (2014). Entrepreneurship and dynamic capabilities: How firm age and size affect the "capability enhancement-SME performance" relationship. Small Business Economics, 42(1), 33-57. https://doi. org/10.1007/s11187-012-9461-9

Arthurs, J. D., \& Busenitz, L. W. (2006). Dynamic capabilities and venture performance: The effects of venture capitalists. Journal of Business Venturing, 21(2), 195-215. https://doi.org/10.1016/j. jbusvent.2005.04.004

Barney, J. B. (1991). Firm resources and sustained competitive advantage. Journal of Management, 17(1), 99-120.

Benson, D., \& Ziedonis, R. H. (2009). Corporate venture capital as a window on new technologies: Implications for the performance of corporate investors when acquiring startups. Organization Science, 20(2), 329-351. https://doi.org/10.1287/orsc.1080.0386

Bergh, P., Thorgren, S., \& Wincent, J. (2011). Entrepreneurs learning together: The importance of building trust for learning and exploiting business opportunities. International Entrepreneurship and Management Journal, 7(1), 17-37. https://doi.org/10.1007/s11365-009-0120-9

Bingham, C. B., \& Davis, J. P. (2012). Learning sequences: Their existence, effect, and evolution. Academy of Management Journal, 55(3), 611-641. https://doi.org/10.5465/amj.2009.0331

Boccardelli, P., \& Magnusson, M. G. (2006). Dynamic capabilities in earlyphase entrepreneurship. Knowledge and Process Management, 13(3), 162-174. https://doi.org/10.1002/kpm.255

Boell, S. K., \& Cecez-Kecmanovic, D. (2015). Debating systematic literature reviews (SLR) and their ramifications for IS: A rejoinder to Mike Chiasson, Briony Oates, Ulrike Schultze, and Richard Watson. Journal of Information Technology, 30(2), 188-193. https://doi.org/10.1057/jit.2015.15

Bower, J., \& Christensen, C. (1995). Disruptive technologies: Catching the wave. Harvard Business Review, (February), 1-17.

Bruneel, J., Yli-Renko, H., \& Clarysse, B. (2010). Learning from experience and learning from others: How congenital and interorganizational learning substitute for experiential learning in young firm internationalization. Strategic Entrepreneurship Journal, 4(2), 164-182. https://doi. org/10.1002/sej.89 
Carayannis, E. G., Provance, M., \& Givens, N. (2011). Knowledge arbitrage, serendipity, and acquisition formality: Their effects on sustainable entrepreneurial activity in regions. IEEE Transactions on Engineering Management, 58(3), 564-577. https://doi.org/10.1109/ TEM.2011.2109725

Carayannis, E. G., Provance, M., \& Grigoroudis, E. (2016). Entrepreneurship ecosystems: An agent-based simulation approach. Journal of Technology Transfer, 41(3), 631-653. https://doi.org/10.1007/s10961-016-9466-7

Clarysse, B., Wright, M., \& Van de Velde, E. (2011). Entrepreneurial origin, technological knowledge, and the growth of spin-off companies. Journal of Management Studies, 48(6), 1420-1442. https://doi.org/10.1111/ j.1467-6486.2010.00991.x

Cohen, W. M., \& Levinthal, D. A. (1990). Absorptive capacity: A new perspective on learning and innovation. Administrative Science Quarterly, 35(1), 128-152.

Crossan, M. M., \& Apaydin, M. (2010). A multi-dimensional framework of organizational innovation: A systematic review of the literature. Journal of Management Studies, 47(6), 1154-1191. https://doi.org/10.1111/ j.1467-6486.2009.00880.x

Dai, Y., Goodale, J. C., Byun, G., \& Ding, F. (2018). Strategic flexibility in new high-technology ventures. Journal of Management Studies, 55(2), 265294. https://doi.org/10.1111/joms.12288

De Clercq, D., Sapienza, H. J., Yavuz, R. I., \& Zhou, L. (2012). Learning and knowledge in early internationalization research: Past accomplishments and future directions. Journal of Business Venturing, 27(1), 143-165. https://doi.org/10.1016/j.jbusvent.2011.09.003

Deeds, D. L. (2001). Role of R\&D intensity, technical development and absorptive capacity in creating entrepreneurial wealth in high technology start-ups. Journal of Engineering and Technology Management, 18(1), 29-47. https://doi.org/10.1016/S0923-4748(00)00032-1

Denyer, D., \& Neely, A. (2004). Introduction to special issue: Innovation and productivity performance in the UK. International Journal of Management Reviews, 5-6(3-4), 131-135. https://doi.org/10.1111/ j.1460-8545.2004.00100.x

Dushnitsky, G., \& Lenox, M. J. (2005a). When do firms undertake R\&D by investing in new ventures? Strategic Management Journal, 26(10), 947965. https://doi.org/10.1002/smj.488

Dushnitsky, G., \& Lenox, M. J. (2005b). When do incumbents learn from entrepreneurial ventures?: Corporate venture capital and investing firm innovation rates. Research Policy, 34(5), 615-639. https://doi. org/10.1016/j.respol.2005.01.017

Eck, N. J. Van, \& Waltman, L. (2018). VOSviewer Manual for VOSviewer version 1.6.9. Retrieved from https://doi.org/10.3402/jac.v8.30072

Edison, H., Smørsgård, N. M., Wang, X., \& Abrahamsson, P. (2018). Lean internal startups for software product innovation in large companies: 
Enablers and inhibitors. Journal of Systems and Software, 135, 69-87. https://doi.org/10.1016/j.jss.2017.09.034

Eggers, J. P. (2012). Falling flat: Failed technologies and investment under uncertainty. Administrative Science Quarterly, 57(1), 47-80. https://doi. org $/ 10.1177 / 0001839212447181$

Engelen, A., Kube, H., Schmidt, S., \& Flatten, T. C. (2014). Entrepreneurial orientation in turbulent environments: The moderating role of absorptive capacity. Research Policy, 43(8), 1353-1369. https://doi.org/10.1016/j. respol.2014.03.002

Fernhaber, S. A., McDougall-Covin, P. P., \& Shepherd, D. A. (2009). International entrepreneurship: Leveraging internal and external knowledge sources. Strategic Entrepreneurship Journal, 3(4), 297-320. https://doi. org $/ 10.1002 /$ sej.76

Friesl, M. (2012). Knowledge acquisition strategies and company performance in young high technology companies. British Journal of Management, 23(3), 325-343. https://doi.org/10.1111/j.1467-8551.2011.00742.x

Giardino, C., Unterkalmsteiner, M., Paternoster, N., Gorschek, T., \& Abrahamsson, P. (2014). What do we know about software development in startups? IEEE Software, 31(5), 28-32. https://doi.org/10.1109/MS.2014.129

Gomes, L. A. de V., Brasil, V. C., Reis de Paula, R. A. S., Facin, A. L. F., Gomes, F. C. de V., \& Salerno, M. S. (2019). Proposing a multilevel approach for the managementofuncertaintiesinexploratoryprojects. ProjectManagement Journal, 50(5), 1-17. https://doi.org/10.1177/8756972819870064

Gomes, L. A. de V., Facin, A. L. F., Salerno, M. S., \& Ikenami, R. K. (2018). Unpacking the innovation ecosystem construct: Evolution, gaps and trends. Technological Forecasting and Social Change, 136, 30-48. https:// doi.org/10.1016/j.techfore.2016.11.009

Grant, R. M. (1996). Toward a knowledge based theory of frim. Strategic Management Journal, 17, 109-122. https://doi.org/10.2307/2486994

Hayter, C. S. (2013). Conceptualizing knowledge-based entrepreneurship networks: Perspectives from the literature. Small Business Economics, 41(4), 899-911. https://doi.org/10.1007/s11187-013-9512-x

Hayton, J. C., \& Zahra, S. A. (2005). Venture team human capital and absorptive capacity in high technology new ventures. International Journal of Technology Management, 31(3/4), 256-274. https://doi.org/10.1504/ IJTM.2005.006634

Helfat, C. E., \& Peteraf, M. A. (2015). Managerial cognitive capabilities and the microfoundations of dynamic capabilities. Strategic Management Journal, 36(6), 831-850. https://doi.org/10.1002/smj.2247

Javalgi, R. G., Hall, K. D., \& Cavusgil, S. T. (2014). Corporate entrepreneurship, customer-oriented selling, absorptive capacity, and international sales performance in the international B2B setting: Conceptual framework and research propositions. International Business Review, 23(6), 11931202. https://doi.org/10.1016/j.ibusrev.2014.04.003 
Kamuriwo, D. S., Baden-Fuller, C., \& Zhang, J. (2017). Knowledge development approaches and breakthrough innovations in technology-based new firms. Journal of Product Innovation Management, 34(4), 492-508. https://doi.org/10.1111/jpim.12393

Knockaert, M., Ucbasaran, D., Wright, M., \& Clarysse, B. (2011). The relationship between knowledge transfer, top management team composition, and performance: The case of science-based entrepreneurial firms. Entrepreneurship: Theory and Practice, 35(4), 777-803. https://doi. org/10.1111/j.1540-6520.2010.00405.x

Kogut, B., \& Zander, U. (1992). Knowledge of the firm, combinative capabilities, and the replication of technology. Organization Science, 3(3), 383-397.

Lane, P. J., \& Lubatkin, M. (1998). Relative absorptive capacity and interorganizational learning. Strategic Management Journal, 19(5), 461477. https://doi.org/10.1002/(SICI)1097-0266(199805)19:5<461::AIDSMJ953>3.3.CO;2-C

Lane, P., Koka, B., \& Pathak, S. (2006). The reification of absorptive capacity: A critical review and rejuvenation of the construct. Academy of Management Review, 31(4), 833-863. https://doi.org/10.5465/ AMR.2006.22527456

Lee, Sang M; Kim, Taewan; Jang, S. H. (2015). Inter-organizational knowledge transfer through corporate venture capital investment. Management Decision, 53(7). https://doi.org/http://dx.doi.org/10.1108/MRR-09-2015-0216

Lis, A., \& Sudolska, A. (2015). Absorptive capacity and its role for the company growth and competitive advantage: The case of Frauenthal Automotive Torun Company. Journal of Entrepreneurship, Management and Innovation, 11(4), 63-91. https://doi.org/10.7341/20151143

Liu, X., Wright, M., Filatotchev, I., Dai, O., \& Lu, J. (2010). Human mobility and international knowledge spillovers: Evidence from high-tech small and medium enterprises in an emerging market. Strategic Entrepreneurship Journal, 4(4), 340-355. https://doi.org/10.1002/sej.100

Lumpkin, G. T., \& Dess, G. G. (1996). Clarifying the entrepreneurial orientation construct and linking it to performance. The Academy of Management Review, 21(1), 135-172. https://doi.org/10.2307/258632

March, J. G. (1991). Exploration and exploitation in organizational learning. Organization Science, 2(1), 71-87. https://doi.org/10.1287/orsc.2.1.71

Marvel, M. (2012). Knowledge acquisition asymmetries and innovation radicalness. Journal of Small Business Management, 50(3), 447-468.

McAdam, M., McAdam, R., Galbraith, B., \& Miller, K. (2010). An exploratory study of principal investigator roles in UK university proof-of-concept processes: An absorptive capacity perspective. $R$ and $D$ Management, 4O(5), 455-473. https://doi.org/10.1111/j.1467-9310.2010.00619.x

McAdam, R., McAdam, M., \& Brown, V. (2009). Proof of concept processes in UK university technology transfer: An absorptive capacity perspective. $R$ and D Management, 39(2), 192-210. https://doi.org/10.1111/j.14679310.2008.00549.x 
McGrath, R. G. (2001). Exploratory learning, innovative capacity, and managerial oversight. Academy of Management Journal, 44(1), 118131. https://doi.org/10.2307/3069340

McKelvie,A., Wiklund,J.,\&Brattström,A. (2018). Externallyacquiredorinternally generated? Knowledge development and perceived environmental dynamism in new venture innovation. Entrepreneurship: Theory and Practice, 42(1), 24-46. https://doi.org/10.1177/1042258717747056

Monferrer, D., Blesa, A., \& Ripollés, M. (2015). Catching dynamic capabilities through market-oriented networks. European J. of International Management, 9(3), 384. https://doi.org/10.1504/EJIM.2015.069134

Moon, S. (2011). What determines the openness of a firm to external knowledge? Evidence from the Korean service sector. Asian Journal of Technology Innovation, 19(2), 185-200. https://doi.org/10.1080/19761 597.2011.630502

Mueller, P. (2006). Exploring the knowledge filter: How entrepreneurship and university-industry relationships drive economic growth. Research Policy, 35(10), 1499-1508. https://doi.org/10.1016/j.respol.2006.09.023

Mueller, P. (2007). Exploiting entrepreneurial opportunities: The impact of entrepreneurship on growth. Small Business Economics, 28(4), 355-362. https://doi.org/10.1007/s11187-006-9035-9

Newbert, S. L. (2005). New firm formation a dynamic capability perspective. Journal of Small Business Management 2005, 43(1), 55-77.

Newey, L. R., \& Zahra, S. A. (2009). The evolving firm: How dynamic and operating capabilities interact to enable entrepreneurship. British Journal of Management, 20(SUPP. 1), S81-S100. https://doi.org/10.1111/j.14678551.2008.00614.x

Nielsen, K. (2015). Human capital and new venture performance: The industry choice and performance of academic entrepreneurs. Journal of Technology Transfer, 4O(3), 453-474. https://doi.org/10.1007/s10961-014-9345-z

Patterson, W., \& Ambrosini, V. (2015). Configuring absorptive capacity as a key process for research intensive firms. Technovation, 36, 77-89. https://doi.org/10.1016/j.technovation.2014.10.003

Patton, D. (2014). Realising potential: The impact of business incubation on the absorptive capacity of new technology-based firms. International Small Business Journal: Researching Entrepreneurship, 32(8), 897-917. https://doi.org/10.1177/0266242613482134

Perez, L., Whitelock, J., \& Florin, J. (2013). Learning about customers: Managing B2B alliances between small technology startups and industry leaders. European Journal of Marketing, 47(3), 431-462. https://doi. org/10.1108/03090561311297409

Podsakoff, P. M., MacKenzie, S. B., Lee, J. Y., \& Podsakoff, N. P. (2003). Common method biases in behavioral research: A critical review of the literature and recommended remedies. Journal of Applied Psychology, 88(5), 879903. https://doi.org/10.1037/0021-9010.88.5.879 
Prashantham, S., \& Young, S. (2011). Post-entry speed of international new ventures. Entrepreneurship: Theory and Practice, 35(2), 275-292. https://doi.org/10.1111/j.1540-6520.2009.00360.x

Qian, H., \& Acs, Z. J. (2013). An absorptive capacity theory of knowledge spillover entrepreneurship. Small Business Economics, 40(2), 185-197. https://doi.org/10.1007/s11187-011-9368-x

Rhee, J. H. (2008). International expansion strategies of Korean venture firms: Entry mode choice and performance. Asian Business \& Management, 7(1), 95-114. https://doi.org/10.1057/palgrave.abm.9200246

Saemundsson, R. J., \& Candi, M. (2017). Absorptive capacity and the identification of opportunities in new technology-based firms. Technovation, 64-65(June), 43-49. https://doi.org/10.1016/j. technovation.2017.06.001

Simsek, Z., \& Heavey, C. (2011). The mediating role of knowledge-based capital for corporate entrepreneurship effects on performance: A study of small- to medium-sized firms. Strategic Entrepreneurship Journal, 5(1), 81-100. https://doi.org/10.1002/sej.108

Sirén, C., Hakala, H., Wincent, J., \& Grichnik, D. (2017). Breaking the routines: Entrepreneurial orientation, strategic learning, firm size, and age. Long Range Planning, 50(2), 145-167. https://doi.org/10.1016/j. Irp.2016.09.005

Spencer, A. S., \& Kirchhoff, B. A. (2006). Schumpeter and new technology based firms: Towards a framework for how NTBFs cause creative destruction. International Entrepreneurship and Management Journal, 2(2), 145-156. https://doi.org/10.1007/s11365-006-8681-3

Sullivan, D. M., \& Marvel, M. R. (2011). Knowledge acquisition, network reliance, and early-stage technology venture outcomes. Journal of Management Studies, 48(6), 1169-1193. https://doi.org/10.1111/ j.1467-6486.2010.00998.x

Teece, D. J. (2007). Explicating dynamic capabilities: The nature and microfoundations of (sustainable) enterprise performance. Strategic Management Journal, 28(13), 1319-1350. https://doi.org/10.1002/smj.640

Teece, D. J. (2012a). Dynamic capabilities: Routines versus entrepreneurial action. Journal of Management Studies, 49(8), 1395-1401. https://doi. org/10.1111/j.1467-6486.2012.01080.x

Teece, D. J., Pisano, G., \& Shuen, A. (1997). Dynamic capabilities and strategic management. Strategic Management Journal, 18(7), 509-533. https:// doi.org/10.1016/B978-0-7506-7088-3.50009-7

Tolstoy, D. (2009). Knowledge combination and knowledge creation in a foreign-market network. Journal of Small Business Management, 47(2), 202-220.

Un, C. A., \& Montoro-Sanchez, A. (2011). R\&D investment and entrepreneurial technological capabilities: Existing capabilities as determinants of new capabilities. International Journal of Technology Management, 54(1), 29-52. https://doi.org/10.5114/pg.2018.74563 
van Eck, N. J., \& Waltman, L. (2010). Software survey: VOSviewer, a computer program for bibliometric mapping. Scientometrics, 84(2), 523-538. https://doi.org/10.1007/s11192-009-0146-3

Volberda, H. W., Foss, N. J., \& Lyles, M. A. (2010). Absorbing the concept of absorptive capacity: How to realize its potential in the organization field. Organization Science, 21(4), 931-951. https://doi.org/10.1287/ orsc.1090.0503

Wadhwa, A., \& Hall, M. (2005). Knowledge creation through external venturing: Evidence from the telecommunication. Academy of Management Journal, 49(4), 819-835. https://doi.org/10.2307/20159800

Wales, W. J., Parida, V., \& Patel, P. C. (2013). Too much of a good thing? Absorptive capacity, firm performance, and the moderating role of entrepreneurial orientation. Strategic Management Journal, 34(5), 622633. https://doi.org/10.1002/smj.2026

Winkelbach, A., \& Walter, A. (2015). Complex technological knowledge and value creation in science-to-industry technology transfer projects: The moderating effect of absorptive capacity. Industrial Marketing Management, 47, 98-108. https://doi.org/10.1016/j. indmarman.2015.02.035

Witt, P. (2004). Entrepreneurs' networks and the success of start-ups. Entrepreneurship and Regional Development, 16(5), 391-412. https:// doi.org/10.1080/0898562042000188423

Yu, J., Gilbert, B. A., \& Oviatt, B. M. (2011). Effects of alliances, time, and network cohesion on the initiation of foreign sales by new ventures. Strategic Management Journal, 32(4), 424-446. https://doi.org/10.1002/smj.884

Zahra, S. A., Filatotchev, I., \& Wright, M. (2009). How do threshold firms sustain corporate entrepreneurship? The role of boards and absorptive capacity. Journal of Business Venturing, 24(3), 248-260. https://doi. org/10.1016/j.jbusvent.2008.09.001

Zahra, S. A., \& George, G. (2002). Absorptive capacity: A review, reconceptualization, and extension. Academy of Management Review, 27(2), 185-203. https://doi.org/10.5465/AMR.2002.6587995

Zahra, S. A., \& Hayton, J. C. (2008). The effect of international venturing on firm performance: The moderating influence of absorptive capacity. Journal of Business Venturing, 23(2), 195-220. https://doi.org/10.1016/j. jbusvent.2007.01.001

Zahra, S. A., Sapienza, H. J., \& Davidsson, P. (2006). Entrepreneurship and dynamic capabilities: A review, model and research agenda. Journal of Management Studies, 43(4), 917-955.

Zheng, Y., Liu, J., \& George, G. (2010). The dynamic impact of innovative capability and inter-firm network on firm valuation: A longitudinal study of biotechnology start-ups. Journal of Business Venturing, 25(6), 593609. https://doi.org/10.1016/j.jbusvent.2009.02.001 
Zuzul, T., \& Tripsas, M. (2019). Start-up Inertia versus flexibility: The role of founder identity in a nascent industry. Administrative Science Quarterly, 1-39. https://doi.org/10.1177/0001839219843486

Appendix A. Coding process of the three clusters of research guidelines

\section{Knowledge cluster}

\begin{tabular}{|c|c|c|c|c|c|c|c|c|c|c|}
\hline AUTHORS & YEAR & JOURNAL & TYPE & AIM OF RESEARCH & RELEVANCE OF AC & METHODOLOGY & SAMPLE & VARIABLES & FINDINGS & $\begin{array}{l}\text { FUTURE RESEARCH } \\
\text { AGENDA }\end{array}$ \\
\hline Mueller & 2006 & RESEARCH POLCY & $\begin{array}{l}\text { Empirical } \\
\text { article }\end{array}$ & $\begin{array}{l}\text { To understand } \\
\text { the role of } \\
\text { entrepreneurship } \\
\text { and university- } \\
\text { industry relations } \\
\text { to acquire new } \\
\text { knowiledge to } \\
\text { contribute to } \\
\text { regional economic } \\
\text { growth. }\end{array}$ & $\begin{array}{l}\text { To identify, capture, } \\
\text { and exploit new } \\
\text { knowledge. }\end{array}$ & $\begin{array}{l}\text { Cobb-Douglas } \\
\text { production } \\
\text { function. Panel } \\
\text { data cross- } \\
\text { sectional time } \\
\text { series. }\end{array}$ & $\begin{array}{l}\text { West German } \\
\text { region } \\
\text { (institutions, } \\
\text { universities, new } \\
\text { ventures, and } \\
\text { firms). }\end{array}$ & $\begin{array}{l}\text { Dependent: } \\
\text { Knowledge related } \\
\text { entrepreneurship } \\
\text { (startups). University- } \\
\text { industry relations } \\
\text { (grants, spillovers, } \\
\text { spinoffs) } \\
\text { Independent: } \\
\text { Economic } \\
\text { Performance. }\end{array}$ & $\begin{array}{l}\text { There is a positive } \\
\text { relationship between } \\
\text { a well-developed } \\
\text { regional knowledge } \\
\text { stock and regional } \\
\text { economic } \\
\text { performance. } \\
\text { Regions with } \\
\text { a higher level of } \\
\text { entrepreneurship } \\
\text { (especially in } \\
\text { innovative industries) } \\
\text { experience } \\
\text { greater economic } \\
\text { performance. } \\
\text { Universities } \\
\text { are a source of } \\
\text { innovation. }\end{array}$ & $\begin{array}{l}\text { Research visibility } \\
\text { of universities' } \\
\text { relevance to regional } \\
\text { growth. Studies on } \\
\text { public policy on } \\
\text { innovation }\end{array}$ \\
\hline Zahra et al. & 2009 & $\begin{array}{l}\text { JOURNAL OF } \\
\text { BUSINESS } \\
\text { VENTURING }\end{array}$ & $\begin{array}{l}\text { Conceptual } \\
\text { article }\end{array}$ & $\begin{array}{l}\text { How threshold } \\
\text { companies (the } \\
\text { intermediate stage } \\
\text { between startup } \\
\text { and established } \\
\text { companies) develop } \\
\text { new capabilities } \\
\text { to improve } \\
\text { performance. }\end{array}$ & $\begin{array}{l}\text { AC has two } \\
\text { major functions: } \\
\text { wealth creation } \\
\text { and protection } \\
\text { of shareholders' } \\
\text { interests. AC allows } \\
\text { threshold companies } \\
\text { to convert their } \\
\text { knowledge into } \\
\text { products goods, and } \\
\text { services that create } \\
\text { wealth. }\end{array}$ & Literature review & - & - & $\begin{array}{l}\text { To develop AC } \\
\text { requires sustained } \\
\text { investments } \\
\text { human resources, } \\
\text { infrastructure, and } \\
\text { research programs. } \\
\text { Managerial } \\
\text { accountability and } \\
\text { AC can sometimes } \\
\text { substitute for each } \\
\text { other while being } \\
\text { complementary. }\end{array}$ & $\begin{array}{l}\text { Follow-up with } \\
\text { empirical research } \\
\text { to validate the } \\
\text { propositions } \\
\text { proposed, } \\
\text { incorporating } \\
\text { measures of } \\
\text { managers'skills } \\
\text { and environmental } \\
\text { conditions. To } \\
\text { examine the } \\
\text { potential interactions } \\
\text { between managerial } \\
\text { accountability } \\
\text { and absortive } \\
\text { capacity at different } \\
\text { thresholds of firms' } \\
\text { evolution. }\end{array}$ \\
\hline $\begin{array}{l}\text { De Clercq } \\
\text { et al. }\end{array}$ & 2012 & $\begin{array}{l}\text { JOURNAL OF } \\
\text { BUSINESS } \\
\text { VENTURING }\end{array}$ & $\begin{array}{l}\text { Conceptual } \\
\text { article }\end{array}$ & $\begin{array}{l}\text { To provide an } \\
\text { evaluative overview } \\
\text { and evaluation } \\
\text { of published } \\
\text { research on the } \\
\text { roles of learning } \\
\text { and knowledge in } \\
\text { early new ventures } \\
\text { internationalization. }\end{array}$ & $\begin{array}{l}\text { To capture new } \\
\text { knowledge based } \\
\text { on the preexisting } \\
\text { knowledge in } \\
\text { outcomes of early } \\
\text { internationalization. }\end{array}$ & $\begin{array}{l}\text { Systematic } \\
\text { Literature review }\end{array}$ & $\begin{array}{l}48 \text { relevant } \\
\text { articles } \\
\text { published } \\
\text { between } 1994 \\
\text { and } 2010 .\end{array}$ & - & $\begin{array}{l}\text { Vicarious and } \\
\text { congenital learning } \\
\text { appear to play } \\
\text { a central pole in the } \\
\text { internationalization } \\
\text { process. Search is } \\
\text { probably the leading } \\
\text { KA type to enhance } \\
\text { the post-entry } \\
\text { performance. } \\
\text { A new venture may } \\
\text { be better able to } \\
\text { absorbo new foreign } \\
\text { knowledge when } \\
\text { it possesses an } \\
\text { extensive knowledge } \\
\text { base. }\end{array}$ & $\begin{array}{l}\text { Further studies } \\
\text { regarding the } \\
\text { individual learning } \\
\text { level, center } \\
\text { on explaining } \\
\text { how a venture } \\
\text { realizes learning } \\
\text { advantages when } \\
\text { internationalizing. }\end{array}$ \\
\hline Acs et al. & 2009 & $\begin{array}{l}\text { SMALL BUSINESS } \\
\text { ECONOMICS }\end{array}$ & $\begin{array}{l}\text { Empirical } \\
\text { article }\end{array}$ & $\begin{array}{l}\text { To develop } \\
\text { a knowledge } \\
\text { spillover theory of } \\
\text { entrepreneurship } \\
\text { to improve the } \\
\text { microeconomic } \\
\text { foundations of } \\
\text { endogenous growth } \\
\text { models. }\end{array}$ & $\begin{array}{l}\text { To acquire new } \\
\text { knowledge. }\end{array}$ & $\begin{array}{l}\text { Longitudinal } \\
\text { panel Itudy. } \\
\text { F-test, } \\
\text { regression } \\
\text { techniques, fixed } \\
\text { effect panels. }\end{array}$ & $\begin{array}{l}\text { Startups data } \\
\text { from World } \\
\text { Bank across } \\
1997-2004 \text { from } \\
19 \text { countries. }\end{array}$ & $\begin{array}{l}\text { Dependent: } \\
\text { Entrepreneurship } \\
\text { Independent: } \\
\text { Knowledge stock. } \\
\text { R\&D explotitation by } \\
\text { incumbents. Barriers } \\
\text { to entrepreneurship. }\end{array}$ & $\begin{array}{l}\text { Entrepreneurial } \\
\text { activity does not } \\
\text { involve only the } \\
\text { creation and the } \\
\text { management of } \\
\text { opportunities, but } \\
\text { also the exploitation } \\
\text { of knowledge not } \\
\text { capitalized by } \\
\text { incumbent firms. }\end{array}$ & $\begin{array}{l}\text { Expand the } \\
\text { explanation about } \\
\text { where opportunities } \\
\text { come from, how } \\
\text { intra-temporal } \\
\text { knowledge spillovers } \\
\text { occur, and the } \\
\text { dynamics of } \\
\text { occupational choice } \\
\text { leading to the new } \\
\text { firm formation. }\end{array}$ \\
\hline $\begin{array}{l}\text { Prashantham } \\
\text { and Young }\end{array}$ & 2011 & $\begin{array}{l}\text { ENTREPRENEURSHIP } \\
\text { THEORY AND } \\
\text { PRACTICE }\end{array}$ & $\begin{array}{l}\text { Conceptual } \\
\text { article }\end{array}$ & $\begin{array}{l}\text { To answer what } \\
\text { explains differential } \\
\text { internationalization } \\
\text { speed among } \\
\text { international new } \\
\text { ventures, after } \\
\text { their initiale entry } \\
\text { into international } \\
\text { markets? }\end{array}$ & $\begin{array}{l}\text { AC allows knowledge } \\
\text { creation and } \\
\text { utilization that } \\
\text { enhances a firm's } \\
\text { ability to gain and } \\
\text { sustain a competitive } \\
\text { advantage. }\end{array}$ & Literature review & - & - & $\begin{array}{l}\text { The pace of } \\
\text { internationalization } \\
\text { varies according } \\
\text { to new ventures' } \\
\text { capabilities in } \\
\text { accumulating and } \\
\text { utillizing knowledge } \\
\text { through exploitative } \\
\text { learning. Social } \\
\text { capital could } \\
\text { facilitate AC. }\end{array}$ & $\begin{array}{l}\text { Empirical research } \\
\text { in order to validate } \\
\text { the propositions } \\
\text { suuggested } \\
\text { incorporating } \\
\text { moderators and } \\
\text { contingencies such a } \\
\text { knowledge-sintensity } \\
\text { of the industry and } \\
\text { firm firm-specific } \\
\text { factors, and home } \\
\text { country effects. }\end{array}$ \\
\hline Bruneel et al. & 2010 & $\begin{array}{l}\text { STRATEGIC } \\
\text { ENTREPRENEURSHIP } \\
\text { JOURNAL }\end{array}$ & $\begin{array}{l}\text { Empirical } \\
\text { article }\end{array}$ & $\begin{array}{l}\text { To address how firms } \\
\text { can accumulate } \\
\text { the knowledge } \\
\text { and skills required } \\
\text { for successful } \\
\text { international } \\
\text { expansion and how } \\
\text { young firms may } \\
\text { compensate for their } \\
\text { lack of firm-level } \\
\text { international } \\
\text { experience by } \\
\text { utilizing other } \\
\text { sources of } \\
\text { knowledge. }\end{array}$ & $\begin{array}{l}\text { Facilitates future } \\
\text { learning of new and } \\
\text { related knowledge. }\end{array}$ & $\begin{array}{l}\text { Survey, multiple } \\
\text { regression, } \\
\text { and sensitivity } \\
\text { analyses. }\end{array}$ & $\begin{array}{l}114 \text { young, } \\
\text { technology- } \\
\text { based firms } \\
\text { in Flanders, } \\
\text { Belgium. }\end{array}$ & $\begin{array}{l}\text { Dependent: Extent of } \\
\text { internationalization. } \\
\text { Independent: } \\
\text { Experiential learning. } \\
\text { Inter-organizational } \\
\text { learning. Congenital } \\
\text { learning. }\end{array}$ & $\begin{array}{l}\text { The firm's experience } \\
\text { in a determined } \\
\text { international market } \\
\text { negatively moderates } \\
\text { the effects of } \\
\text { congenital and } \\
\text { inter-organizational } \\
\text { learning. The } \\
\text { lower the startup's } \\
\text { experiential learning, } \\
\text { the more the } \\
\text { effects of the team's } \\
\text { prior international } \\
\text { knowledge base and } \\
\text { skills obtained by key } \\
\text { partners. }\end{array}$ & $\begin{array}{l}\text { To conduct other } \\
\text { empirical researches } \\
\text { with larger samples } \\
\text { in other regions } \\
\text { and industries, and } \\
\text { also longitudinal } \\
\text { studies to analyze } \\
\text { the dynamics } \\
\text { of learning and } \\
\text { internationalization. }\end{array}$ \\
\hline
\end{tabular}




\begin{tabular}{|c|c|c|c|c|c|c|c|c|c|c|}
\hline AUTHORS & YEAR & JOURNAL & TYPE & AIM OF RESEARCH & RELEVANCE OF AC & METHODOLOGY & SAMPLE & VARIABLES & FINDINGS & $\begin{array}{l}\text { FUTURE RESEARCH } \\
\text { AGENDA }\end{array}$ \\
\hline $\begin{array}{l}\text { Fernhaber } \\
\text { et al. }\end{array}$ & 2009 & $\begin{array}{l}\text { STRATEGIC } \\
\text { ENTREPRENEURSHIP } \\
\text { JOURNAL }\end{array}$ & $\begin{array}{l}\text { Empirical } \\
\text { article }\end{array}$ & $\begin{array}{l}\text { To develop } \\
\text { a knowledge- } \\
\text { based model of } \\
\text { internationalization } \\
\text { to investigate } \\
\text { the role of } \\
\text { external sources } \\
\text { of international } \\
\text { knowledge }\end{array}$ & $\begin{array}{l}\text { AC is recognized as } \\
\text { an organizational } \\
\text { mechanism for } \\
\text { integrating internal } \\
\text { and external sources } \\
\text { of knowledge. }\end{array}$ & $\begin{array}{l}\text { Longitudinal } \\
\text { panel study. } \\
\text { Interval } \\
\text { regressions and } \\
\text { correlations. }\end{array}$ & $\begin{array}{l}206 \text { U.S. high } \\
\text { technology } \\
\text { new ventures } \\
\text { between 1996- } \\
2000 \text {. }\end{array}$ & $\begin{array}{l}\text { Dependent: } \\
\text { New venture } \\
\text { internationalization } \\
\text { Independent: } \\
\text { Alliance partner } \\
\text { int' knowledge. } \\
\text { Venture Capital } \\
\text { int'l knowledge. } \\
\text { Proximal firm int'l } \\
\text { knowledge }\end{array}$ & $\begin{array}{l}\text { External sources } \\
\text { are positively } \\
\text { associated with } \\
\text { a startup's level of } \\
\text { internationalization. } \\
\text { The nature of } \\
\text { external sources } \\
\text { of international } \\
\text { knowledge } \\
\text { depended on } \\
\text { the international } \\
\text { knowlenge of the } \\
\text { new venture's team. }\end{array}$ & $\begin{array}{l}\text { Additional tests } \\
\text { using other samples, } \\
\text { and comparing } \\
\text { new and mature } \\
\text { firms to analyze } \\
\text { the differences. } \\
\text { To include the } \\
\text { international entry } \\
\text { year as a control } \\
\text { variable. And to } \\
\text { examine how } \\
\text { external sources of } \\
\text { knowledge impact } \\
\text { a new venture's } \\
\text { country location } \\
\text { decision, taking } \\
\text { into consideration } \\
\text { country differences. }\end{array}$ \\
\hline Yuet al. & 2011 & $\begin{array}{l}\text { STRATEGIC } \\
\text { MANAGEMENT } \\
\text { JOURNAL }\end{array}$ & $\begin{array}{l}\text { Empirical } \\
\text { article }\end{array}$ & $\begin{array}{l}\text { To examine the } \\
\text { role of networks in } \\
\text { accelerating new } \\
\text { venture sales into } \\
\text { foreign markets }\end{array}$ & $\begin{array}{l}\text { To help young } \\
\text { ventures to learn } \\
\text { new knowledge in } \\
\text { foreign markets }\end{array}$ & $\begin{array}{l}\text { Longitudinal } \\
\text { panel study. Cox } \\
\text { proportional } \\
\text { hazard models, } \\
\text { regressions, and } \\
\text { correlations. } \\
\text { Kaplan-Meier } \\
\text { analysis. }\end{array}$ & $\begin{array}{l}\text { Longitudinal } \\
\text { dataset of } 118 \\
\text { new ventures in } \\
\text { the U.S (1990- } \\
\text { 2000). }\end{array}$ & $\begin{array}{l}\text { Dependent: Venture } \\
\text { initiation of foreign } \\
\text { sales. } \\
\text { Independent: } \\
\text { Technology expertise } \\
\text { of technology } \\
\text { alliance partners. } \\
\text { Marketing alliances } \\
\text { with foreign firms. } \\
\text { Marketing alliances } \\
\text { with internationally } \\
\text { experienced } \\
\text { domestic firms. } \\
\text { Network cohesion, } \\
\text { Time. }\end{array}$ & $\begin{array}{l}\text { Knowledge derived } \\
\text { from ventures' } \\
\text { technology and } \\
\text { marketing alliances } \\
\text { increases the } \\
\text { likelihood that } \\
\text { startups exploit } \\
\text { opportunities } \\
\text { in international } \\
\text { markets. The } \\
\text { probability of } \\
\text { a startup initiating } \\
\text { foreign sales may } \\
\text { be altered by the } \\
\text { technological } \\
\text { and marketing } \\
\text { relationships } \\
\text { and by the time } \\
\text { required for process } \\
\text { knowledge ard to } \\
\text { exploit international } \\
\text { opportunities }\end{array}$ & $\begin{array}{l}\text { New empirical } \\
\text { studies considering } \\
\text { other righhtech } \\
\text { industries, } \\
\text { environents, and } \\
\text { characteristics. } \\
\text { To study how } \\
\text { a venture's } \\
\text { alliance network } \\
\text { influences its } \\
\text { degree and scope of } \\
\text { internationalization } \\
\text { through longitudinal } \\
\text { analyses. }\end{array}$ \\
\hline $\begin{array}{l}\text { Bingham, and } \\
\text { Davis }\end{array}$ & 2012 & $\begin{array}{l}\text { ACADEMY OF } \\
\text { MANAGEMENT } \\
\text { JOURNAL }\end{array}$ & $\begin{array}{l}\text { Conceptual } \\
\text { article }\end{array}$ & $\begin{array}{l}\text { To understand } \\
\text { whether the distinct } \\
\text { learning processes } \\
\text { that organizations } \\
\text { use (e.e., trial-and- } \\
\text { error learning, } \\
\text { vicarious learning, } \\
\text { experimental } \\
\text { learning, and } \\
\text { improvisational } \\
\text { learning) combine } \\
\text { over time in ordered } \\
\text { ways. }\end{array}$ & $\begin{array}{l}\text { To identify and } \\
\text { capture new } \\
\text { knowledge. }\end{array}$ & $\begin{array}{l}\text { Theory-building } \\
\text { (Eisenhardt, } \\
\text { 1989) and } \\
\text { theory } \\
\text { elaboration } \\
\text { methods } \\
\text { (Lee, 1999). } \\
\text { Semi-structured } \\
\text { interviews. } \\
\text { Case-study }\end{array}$ & $\begin{array}{l}9 \\
\text { entrepreneurial } \\
\text { firms with } \\
\text { headquarters } \\
\text { in Singapore, } \\
\text { the U.S., and } \\
\text { Finland. }\end{array}$ & - & $\begin{array}{l}\text { Learning sequences } \\
\text { (LS) exist, evolve, } \\
\text { and are influenced } \\
\text { by initial conditions. } \\
\text { IL have } 2 \text { patterns: } \\
\text { seeding and soloing. } \\
\text { These } 2 \text { partterss vary } \\
\text { across firms, and the } \\
\text { team's international } \\
\text { experience } \\
\text { influences their } \\
\text { adoption. }\end{array}$ & $\begin{array}{l}\text { Empirical studies } \\
\text { with a broader } \\
\text { sample. }\end{array}$ \\
\hline $\begin{array}{l}\text { Sullivan and } \\
\text { Marvel }\end{array}$ & 2011 & $\begin{array}{l}\text { JOURNAL OF } \\
\text { MANAGEMENT } \\
\text { STUDESS }\end{array}$ & $\begin{array}{l}\text { Empirical } \\
\text { article }\end{array}$ & $\begin{array}{l}\text { The article } \\
\text { examines how an } \\
\text { entrepreneur's } \\
\text { acquisition of } \\
\text { different types } \\
\text { of knowledge } \\
\text { and reliance on } \\
\text { their network for } \\
\text { knowledger elate } \\
\text { to outcomes of } \\
\text { product } \\
\text { innovativerice } \\
\text { first-yearesess and venture } \\
\text { sales. }\end{array}$ & $\begin{array}{l}\text { AC allows } \\
\text { entrepreneurs } \\
\text { to understand, } \\
\text { assimilate, and apply } \\
\text { new knowledge } \\
\text { more effectively. }\end{array}$ & $\begin{array}{l}\text { Survey, OLS } \\
\text { regression, } \\
\text { sensitivity } \\
\text { analyses, } \\
\text { hierarchical } \\
\text { moderated } \\
\text { multiple } \\
\text { regression } \\
\text { analysis, test of } \\
\text { the slopes. }\end{array}$ & $\begin{array}{l}151 \text { venture } \\
\text { founders from } \\
16 \text { technology } \\
\text { incubators in } \\
\text { the USA. }\end{array}$ & $\begin{array}{l}\text { Dependent: First- } \\
\text { year venture sales. } \\
\text { Product/service } \\
\text { innovativeness. } \\
\text { Independent: } \\
\text { Knowledge } \\
\text { acquisition. } \\
\text { Moderator: Network } \\
\text { reliance on acquiring } \\
\text { technology and } \\
\text { market knowledge. }\end{array}$ & $\begin{array}{l}\text { Acquiring technology } \\
\text { knowledge } \\
\text { positively affects } \\
\text { the innovativeness } \\
\text { of a new venture. } \\
\text { Entrepreneurs } \\
\text { can enhance } \\
\text { this relationship } \\
\text { by relying more } \\
\text { on networks } \\
\text { for technology } \\
\text { knowledge } \\
\text { acquisition. }\end{array}$ & $\begin{array}{l}\text { To conduct other } \\
\text { empirical researches } \\
\text { with larger samples } \\
\text { in other regions. } \\
\text { Expand the } \\
\text { understanding of the } \\
\text { type of networks' } \\
\text { reliance and the } \\
\text { potential AC. }\end{array}$ \\
\hline Agarwal et al. & 2010 & $\begin{array}{l}\text { STRATEGIC } \\
\text { ENTREPRENEURSHIP } \\
\text { JOURNAL }\end{array}$ & $\begin{array}{l}\text { Conceptual } \\
\text { article }\end{array}$ & $\begin{array}{l}\text { To develop } \\
\text { implications of } \\
\text { the link between } \\
\text { knowledge spillovers } \\
\text { and strategic } \\
\text { entrepreneurship } \\
\text { and identify key } \\
\text { topics, themes, and } \\
\text { issues for future } \\
\text { research. }\end{array}$ & $\begin{array}{l}\text { The ability to identify } \\
\text { and value new ideas, } \\
\text { including those of } \\
\text { supply-side agents. }\end{array}$ & Literature review & - & - & $\begin{array}{l}\text { Knowledge spillovers } \\
\text { and strategic } \\
\text { entrepreneurship } \\
\text { are linked to each } \\
\text { other, and examining } \\
\text { this relationship } \\
\text { is important } \\
\text { to understand } \\
\text { the causes and } \\
\text { consequences of } \\
\text { value creation and } \\
\text { appropriation, } \\
\text { diffusion of } \\
\text { knowledge, rrowth, } \\
\text { and prosperity } \\
\text { of regions and } \\
\text { nations. }\end{array}$ & $\begin{array}{l}\text { To research impact } \\
\text { on knowledge } \\
\text { spillovers } \\
\text { and strategic } \\
\text { entrepreneurship } \\
\text { within and across } \\
\text { organizational } \\
\text { contexts, the } \\
\text { underlying } \\
\text { mechanisms that } \\
\text { relate knowledge } \\
\text { spillovers } \\
\text { and strategic } \\
\text { entrepreneurship } \\
\text { (among other } \\
\text { research questions) }\end{array}$ \\
\hline Mueller & 2007 & $\begin{array}{l}\text { SMALL BUSINESS } \\
\text { ECONOMICS }\end{array}$ & $\begin{array}{l}\text { Empirical } \\
\text { article }\end{array}$ & $\begin{array}{l}\text { To identify } \\
\text { whether or not } \\
\text { entrepreneurship is } \\
\text { an important vehicle } \\
\text { for knowledge } \\
\text { flows and economic } \\
\text { growth. }\end{array}$ & $\begin{array}{l}\text { To identify, capture, } \\
\text { and exploit new } \\
\text { knowledge. }\end{array}$ & $\begin{array}{l}\text { Longitudinal } \\
\text { panel study. } \\
\text { Cobb-Douglas } \\
\text { production } \\
\text { function and } \\
\text { regressions. }\end{array}$ & $\begin{array}{l}74 \text { planning } \\
\text { regions in West } \\
\text { Germany (1990- } \\
\text { 2002). }\end{array}$ & $\begin{array}{l}\text { Dependent: Regional } \\
\text { economic growth. } \\
\text { Independent: } \\
\text { Entrepreneurship. } \\
\text { Knowledge creation. }\end{array}$ & $\begin{array}{l}\text { A strong regional } \\
\text { knowledge stock is } \\
\text { central to economic } \\
\text { growth. New } \\
\text { knowledge in private } \\
\text { firms is more likely } \\
\text { to be converted into } \\
\text { new productcs or } \\
\text { services. However, } \\
\text { research in public } \\
\text { organizations is often } \\
\text { characterized by } \\
\text { basic research which } \\
\text { is very important } \\
\text { for the regional and } \\
\text { national knowledge } \\
\text { stock. }\end{array}$ & $\begin{array}{l}\text { Empirical studies } \\
\text { with a broader } \\
\text { sample. }\end{array}$ \\
\hline $\begin{array}{l}\text { Knockaert } \\
\text { et al. }\end{array}$ & 2011 & $\begin{array}{l}\text { ENTREPRENEURSHIP } \\
\text { THEORY AND } \\
\text { PRACTICE }\end{array}$ & $\begin{array}{l}\text { Conceptual } \\
\text { article }\end{array}$ & $\begin{array}{l}\text { To assess how } \\
\text { knowledge can } \\
\text { be transferred } \\
\text { and employed } \\
\text { in Science-based } \\
\text { entrepreneurial } \\
\text { firms (SBEF) in } \\
\text { order to enhance its } \\
\text { performance. }\end{array}$ & $\begin{array}{l}\text { To identify, use, and } \\
\text { transfer knowledge } \\
\text { successfully. }\end{array}$ & $\begin{array}{l}\text { Longitudinal } \\
\text { inductive case } \\
\text { study approach. }\end{array}$ & $\begin{array}{l}9 \text { SBEFs } \\
\text { from Inter } \\
\text { University Micro } \\
\text { Electronics } \\
\text { Centre, } \\
\text { Belgium. }\end{array}$ & - & $\begin{array}{l}\text { Tacit knowledge is } \\
\text { better transferred } \\
\text { when a substantial } \\
\text { part of the former } \\
\text { research team } \\
\text { become founders of } \\
\text { the new venture. }\end{array}$ & $\begin{array}{l}\text { Further research } \\
\text { studying a matched } \\
\text { sample of SBEFs in } \\
\text { the early stages that } \\
\text { failed and succeeded } \\
\text { in order to compare } \\
\text { them and to identify } \\
\text { which specific types } \\
\text { of tacit knowledge } \\
\text { is crucial to enhance } \\
\text { SBEF performance. }\end{array}$ \\
\hline
\end{tabular}




\begin{tabular}{|c|c|c|c|c|c|c|c|c|c|c|}
\hline AUTHORS & YEAR & JOURNAL & TYPE & AIM OF RESEARCH & RELEVANCE OF AC & METHODOLOGY & SAMPLE & VARIABLES & FINDINGS & $\begin{array}{l}\text { FUTURE RESEARCH } \\
\text { AGENDA }\end{array}$ \\
\hline Qian and Acs & 2013 & $\begin{array}{l}\text { SMALL BUSINESS } \\
\text { ECONOMICS }\end{array}$ & $\begin{array}{l}\text { Conceptual } \\
\text { article with } \\
\text { empirical } \\
\text { evidence }\end{array}$ & $\begin{array}{l}\text { To propose a better } \\
\text { understanding of } \\
\text { how entrepreneurial } \\
\text { activity builds } \\
\text { knowledge. }\end{array}$ & $\begin{array}{l}\text { To allow } \\
\text { entrepreneurs } \\
\text { to understand } \\
\text { new knowledge, } \\
\text { recognize its value, } \\
\text { and commercialize it. }\end{array}$ & $\begin{array}{l}\text { Literature } \\
\text { review. } \\
\text { Correlation } \\
\text { matrix, path } \\
\text { analysis, } \\
\text { regressions. }\end{array}$ & $\begin{array}{l}\text { Patent data from } \\
\text { the U.S. Patent } \\
\text { and Trademark } \\
\text { Office. } 305 \\
\text { MSAS/PMSAs }\end{array}$ & $\begin{array}{l}\text { Dependent: } \\
\text { New knowledge. } \\
\text { Entrepreneurship. } \\
\text { Independent: } \\
\text { Human capital. New } \\
\text { knowledge. }\end{array}$ & $\begin{array}{l}\text { Knowledge spillover } \\
\text { entrepreneurship } \\
\text { depends on new } \\
\text { knowledge and } \\
\text { entrepreneurial } \\
\text { AC EACC, defined } \\
\text { as the "ability of } \\
\text { an entrepreneur } \\
\text { to understand } \\
\text { new knowledge, } \\
\text { recognize its value, } \\
\text { and subsequently } \\
\text { commercialize it by } \\
\text { creating a firm" }\end{array}$ & $\begin{array}{l}\text { Additional empirical } \\
\text { work using an } \\
\text { individual unit of } \\
\text { analysis (surveys } \\
\text { with entrepreneurs). }\end{array}$ \\
\hline Tolstoy & 2009 & $\begin{array}{l}\text { JOURNAL OF } \\
\text { SMAL BUSINESS } \\
\text { MANAGEMENT }\end{array}$ & $\begin{array}{l}\text { Empirical } \\
\text { article }\end{array}$ & $\begin{array}{l}\text { To investigate the } \\
\text { prospective impact } \\
\text { network knowledge } \\
\text { and knowledge } \\
\text { combinations have } \\
\text { on entrepreneurial } \\
\text { firms' knowledge } \\
\text { creation. }\end{array}$ & $\begin{array}{l}\text { It is the mechanism } \\
\text { by which firms } \\
\text { identify, acquire, } \\
\text { and exploit new } \\
\text { knowledge. }\end{array}$ & $\begin{array}{l}\text { Survey, } \\
\text { Structural } \\
\text { equation } \\
\text { model, using } \\
\text { linear structural } \\
\text { relations } \\
\text { (USREL). }\end{array}$ & $\begin{array}{l}\text { Random } \\
\text { sample of 188 } \\
\text { international } \\
\text { SMEs from } \\
\text { Statistics } \\
\text { Sweden Business } \\
\text { Register }\end{array}$ & $\begin{array}{l}\text { Dependent: } \\
\text { Knowledge creation. } \\
\text { Knowledge } \\
\text { combination. } \\
\text { Independent: } \\
\text { Dependence on } \\
\text { customer knowledge. } \\
\text { Dependence on } \\
\text { supplier knowledge. }\end{array}$ & $\begin{array}{l}\text { Knowledge } \\
\text { combination is } \\
\text { a predominant } \\
\text { activity to enable } \\
\text { knowledge creation } \\
\text { in foreign markets. } \\
\text { In order to create } \\
\text { knowledge to } \\
\text { commercialize } \\
\text { products and } \\
\text { services, firms } \\
\text { must constantly } \\
\text { revamp knowledge } \\
\text { by combining it in } \\
\text { new ways. }\end{array}$ & $\begin{array}{l}\text { Further investigation } \\
\text { regarding the } \\
\text { processes involving } \\
\text { knowledge } \\
\text { combination and } \\
\text { knowledge creation } \\
\text { in foreignn-market } \\
\text { networks of } \\
\text { international } \\
\text { entrepreneurs, and } \\
\text { the cost of creating } \\
\text { knowledge in } \\
\text { exterenal networks } \\
\text { rather than in } \\
\text { a firm's internal } \\
\text { network. }\end{array}$ \\
\hline $\begin{array}{l}\text { Hayton and } \\
\text { Zahra }\end{array}$ & 2005 & $\begin{array}{l}\text { INTERNATIONAL } \\
\text { JOURNAL OF } \\
\text { TECHNOLOGY } \\
\text { MANAGEMENT }\end{array}$ & $\begin{array}{l}\text { Empirical } \\
\text { article }\end{array}$ & $\begin{array}{l}\text { To examine the } \\
\text { extent to which } \\
\text { the AC of high } \\
\text { technology } \\
\text { new ventures is } \\
\text { influenced by the } \\
\text { human capital } \\
\text { characteristics } \\
\text { of their top } \\
\text { management teams } \\
\text { (TMT). }\end{array}$ & $\begin{array}{l}\text { AC is the ability to } \\
\text { identify, acquire, } \\
\text { assimilate, and } \\
\text { exploit new } \\
\text { knowledge. }\end{array}$ & $\begin{array}{l}\text { Survey, } \\
\text { Hierarchical } \\
\text { regressions, and } \\
\text { correlations. }\end{array}$ & $\begin{array}{l}340 \text { high } \\
\text { technology new } \\
\text { ventures from } \\
\text { the USA. }\end{array}$ & $\begin{array}{l}\text { Dependent: } \\
\text { Innovation. Financial } \\
\text { performance. } \\
\text { Independent: } \\
\text { Venturing. Human } \\
\text { capital. }\end{array}$ & $\begin{array}{l}\text { Human capital } \\
\text { diversity of the } \\
\text { TMT moderates } \\
\text { the relationship } \\
\text { between venturing } \\
\text { activities, innovation, } \\
\text { and financial } \\
\text { performance. The } \\
\text { diversity of the } \\
\text { TMT in terms of } \\
\text { both functional } \\
\text { experience and } \\
\text { formal educational } \\
\text { background can } \\
\text { enhance the } \\
\text { acquisition and } \\
\text { exploitation of new } \\
\text { knowledge. }\end{array}$ & $\begin{array}{l}\text { To consider } \\
\text { alternativin indicators } \\
\text { of human capital of } \\
\text { top management } \\
\text { and to examine } \\
\text { the roles of the } \\
\text { TMT characteristics } \\
\text { in organizational } \\
\text { learning from } \\
\text { venturing activities. }\end{array}$ \\
\hline $\begin{array}{l}\text { Carayannis } \\
\text { et al. }\end{array}$ & 2011 & $\begin{array}{l}\text { IEEE TRANSACTIONS } \\
\text { ON ENGINEERING } \\
\text { MANAGEMENT }\end{array}$ & $\begin{array}{l}\text { Empirical } \\
\text { article }\end{array}$ & $\begin{array}{l}\text { To examine the } \\
\text { roles of nnowledge } \\
\text { accuisition and } \\
\text { transformation } \\
\text { in regional } \\
\text { sustainability of new } \\
\text { venture formation. }\end{array}$ & $\begin{array}{l}\text { The means by } \\
\text { which new venture } \\
\text { founders incorporate } \\
\text { new knowledge into } \\
\text { their organizations. }\end{array}$ & $\begin{array}{l}\text { Agent-based } \\
\text { simulation. } \\
30 \text { runs of the } \\
\text { simulation in six } \\
\text { configurations. } \\
\text { F-statistics. }\end{array}$ & - & $\begin{array}{l}\text { Dependent: New } \\
\text { venture formation. } \\
\text { Independent: } \\
\text { Formal knowledge } \\
\text { acquisition. } \\
\text { Serendipitous } \\
\text { knowledge } \\
\text { transformation. }\end{array}$ & $\begin{array}{l}\text { Formal knowledge } \\
\text { acquisition is } \\
\text { more effective in } \\
\text { knowledge-scarce } \\
\text { regions, while } \\
\text { informal knowledge } \\
\text { acquisition and } \\
\text { serendipipity are more } \\
\text { appropriated for new } \\
\text { venture formation } \\
\text { in knowledge-rich } \\
\text { regions. }\end{array}$ & $\begin{array}{l}\text { Empirical tests to } \\
\text { validate the models } \\
\text { and to analyze the } \\
\text { rate and quality } \\
\text { of new venture } \\
\text { dynamics }\end{array}$ \\
\hline Patton & 2014 & $\begin{array}{l}\text { INTERNATIONAL } \\
\text { SMAL BUSINESS } \\
\text { JOURNAL }\end{array}$ & $\begin{array}{l}\text { Empirical } \\
\text { article }\end{array}$ & $\begin{array}{l}\text { To analyze the } \\
\text { incubation process } \\
\text { through the lens } \\
\text { of AC in order to } \\
\text { evaluate how it } \\
\text { might strengthen } \\
\text { the business model } \\
\text { of new technology } \\
\text { firms. }\end{array}$ & $\begin{array}{l}\text { AC enables } \\
\text { knowledge } \\
\text { development and } \\
\text { critically, facilitating } \\
\text { the transformation } \\
\text { of knowledge into } \\
\text { a resource which } \\
\text { supports business } \\
\text { development and } \\
\text { sustainability. }\end{array}$ & Case study & $\begin{array}{l}27 \text { new firms at } \\
\text { two University } \\
\text { incubators at } \\
\text { Southampton } \\
\text { and ristol } \\
\text { between } 2009 \\
\text { and 2011. }\end{array}$ & - & $\begin{array}{l}\text { The interaction } \\
\text { between incubator } \\
\text { directors, mentors, } \\
\text { and business } \\
\text { support agents } \\
\text { enables experiential } \\
\text { and exploitative } \\
\text { learning, which } \\
\text { are the precursors } \\
\text { of knowledge } \\
\text { accumulation. }\end{array}$ & $\begin{array}{l}\text { Future research } \\
\text { needs to investigate } \\
\text { how the incubation } \\
\text { process creates } \\
\text { a context which } \\
\text { encourages founders } \\
\text { to engage with } \\
\text { those who can assist } \\
\text { the accumulation } \\
\text { of the knowledge } \\
\text { to develop } \\
\text { a commercial } \\
\text { business model. }\end{array}$ \\
\hline Perez et al. & 2013 & $\begin{array}{l}\text { EUROPEAN JOURNAL } \\
\text { OF MARKETING }\end{array}$ & $\begin{array}{l}\text { Empirical } \\
\text { article }\end{array}$ & $\begin{array}{l}\text { To gain a better } \\
\text { understanding } \\
\text { of how small } \\
\text { technology start-ups } \\
\text { learn about a key } \\
\text { customer in the } \\
\text { context of } B 2 B \\
\text { relationships, and } \\
\text { to propose a model } \\
\text { of interfirm learning } \\
\text { with customers }\end{array}$ & $\begin{array}{l}\text { The ability of } \\
\text { a firm to recognize } \\
\text { the value of new, } \\
\text { external information, } \\
\text { assimilate, and apply } \\
\text { it to commercial } \\
\text { ends and enhance } \\
\text { innovative } \\
\text { performance. }\end{array}$ & $\begin{array}{l}\text { Qualitative case- } \\
\text { based approach } \\
\text { over two to } \\
\text { three years. }\end{array}$ & $\begin{array}{l}\text { Three cases } \\
\text { of alliances to } \\
\text { develop new } \\
\text { products or } \\
\text { technologies } \\
\text { between } \\
\text { a young } \\
\text { technology firm } \\
\text { and a large, } \\
\text { well-established } \\
\text { customer. }\end{array}$ & - & $\begin{array}{l}\text { A similar knowledge } \\
\text { base affects } \\
\text { positively the new } \\
\text { venture's ability } \\
\text { to learn about } \\
\text { customers. Learning- } \\
\text { by-interacting } \\
\text { is beneficial for } \\
\text { technology start-ups } \\
\text { to access new } \\
\text { markets and new } \\
\text { resources to develop } \\
\text { innovative solutions } \\
\text { that could not have } \\
\text { been developed } \\
\text { alone. }\end{array}$ & $\begin{array}{l}\text { Further research } \\
\text { using large-scale } \\
\text { longitudinal studies } \\
\text { and considering the } \\
\text { effect of interf firm } \\
\text { market orientation } \\
\text { on performance and } \\
\text { innovation. }\end{array}$ \\
\hline
\end{tabular}




\begin{tabular}{|c|c|c|c|c|c|c|c|c|c|c|}
\hline AUTHORS & YEAR & JOURNAL & TYPE & AIM OF RESEARCH & RELEVANCE OF AC & METHODOLOGY & SAMPLE & VARIABLES & FINDINGS & $\begin{array}{l}\text { FUTURE RESEARCH } \\
\text { AGENDA }\end{array}$ \\
\hline Friesl & 2012 & $\begin{array}{l}\text { BRITISH JOURNAL OF } \\
\text { MANAGEMENT }\end{array}$ & $\begin{array}{l}\text { Empirical } \\
\text { article }\end{array}$ & $\begin{array}{l}\text { To delineate } \\
\text { the relatitionship } \\
\text { of activity } \\
\text { configurations } \\
\text { for knowledge } \\
\text { acquisition } \\
\text { and company } \\
\text { performance. }\end{array}$ & $\begin{array}{l}\text { AC helps firms to } \\
\text { identify, acquire, } \\
\text { and use knowledge } \\
\text { that affects firms' } \\
\text { performance and } \\
\text { innovativeness. }\end{array}$ & $\begin{array}{l}11 \text { semi- } \\
\text { structured } \\
\text { interviews. } \\
\text { Survey, 88 } \\
\text { CEOS. Multiple } \\
\text { regressions and } \\
\text { correlations } \\
\text { analysis. } \\
\text { ANOV. }\end{array}$ & $\begin{array}{l}\text { Young } \\
\text { biotechnology } \\
\text { companies in } \\
\text { Germany. }\end{array}$ & $\begin{array}{l}\text { Dependent: } \\
\text { Performance. } \\
\text { Independent: } \\
\text { Knowledge } \\
\text { acquisition } \\
\text { strategies. }\end{array}$ & $\begin{array}{l}\text { There are four } \\
\text { knowledge } \\
\text { acquisition strategies } \\
\text { for knowledge } \\
\text { acquisition and } \\
\text { performance: low } \\
\text { key, mid-range, } \\
\text { focus, and explorer. } \\
\text { Knowledge } \\
\text { acquisition strategies } \\
\text { that show a high } \\
\text { intensity and that } \\
\text { combine both } \\
\text { complementary } \\
\text { and supplementary } \\
\text { knowledge } \\
\text { acquisition are } \\
\text { linked to higher } \\
\text { levels of company } \\
\text { performance. }\end{array}$ & $\begin{array}{l}\text { To conduct other } \\
\text { empirical researches } \\
\text { with larger } \\
\text { samples in other } \\
\text { regions and with } \\
\text { a greater number } \\
\text { of respondents. } \\
\text { New studies aiming } \\
\text { to investigate how } \\
\text { young companies } \\
\text { actually orchestrate } \\
\text { knowledge } \\
\text { acquisition in } \\
\text { practice. }\end{array}$ \\
\hline Moon & 2011 & $\begin{array}{l}\text { ASIAN JOURNAL } \\
\text { OF EECHNOLOGY } \\
\text { INNOVATION }\end{array}$ & $\begin{array}{l}\text { Empirical } \\
\text { article }\end{array}$ & $\begin{array}{l}\text { To examine the } \\
\text { factors that influence } \\
\text { a firm's openness } \\
\text { to external sources } \\
\text { of knowledge in } \\
\text { the Korean service } \\
\text { sector. }\end{array}$ & $\begin{array}{l}\text { To recognize the } \\
\text { value of new, } \\
\text { external information, } \\
\text { assimilate it, } \\
\text { and apply it to } \\
\text { commercial ends. }\end{array}$ & $\begin{array}{l}\text { Survey. Negative } \\
\text { binomial } \\
\text { regression, } \\
\text { correlations, } \\
\text { Tobit regression. }\end{array}$ & $\begin{array}{l}2498 \text { Korean } \\
\text { service new } \\
\text { firms }\end{array}$ & $\begin{array}{l}\text { Dependent: Degree } \\
\text { of openness to } \\
\text { external knowledge } \\
\text { sources. } \\
\text { Independent: } \\
\text { Overall tightness of } \\
\text { appropriability of } \\
\text { a firm. The share } \\
\text { of employees with } \\
\text { graduate degrees. } \\
\text { Whether a firm is } \\
\text { a startup. Firm size. }\end{array}$ & $\begin{array}{l}\text { The appropriability } \\
\text { strategry, the share } \\
\text { of employees with } \\
\text { graduate degrees, } \\
\text { being a startup, } \\
\text { and firm size } \\
\text { seem to be major } \\
\text { determinants of the } \\
\text { openness to external } \\
\text { knowledge sources } \\
\text { in Korean service } \\
\text { industries. The } \\
\text { use of intellectual } \\
\text { property rights may } \\
\text { not be effective } \\
\text { in enhancing the } \\
\text { openness to external } \\
\text { knowledge in Korean } \\
\text { service industries, } \\
\text { it may eventually } \\
\text { restrict the incentive } \\
\text { to use external } \\
\text { knowledge. }\end{array}$ & $\begin{array}{l}\text { To develop the } \\
\text { measures of AC in } \\
\text { terms of human } \\
\text { capital and skill } \\
\text { and to compare } \\
\text { the determinants } \\
\text { of openness in the } \\
\text { manufacturing and } \\
\text { service sectors. }\end{array}$ \\
\hline $\begin{array}{l}\text { Carayannis } \\
\text { et al. }\end{array}$ & 2016 & $\begin{array}{l}\text { JOURNAL OF } \\
\text { TECHNOLOGY } \\
\text { TRANSFER }\end{array}$ & $\begin{array}{l}\text { Empirical } \\
\text { article }\end{array}$ & $\begin{array}{l}\text { To examine the } \\
\text { influence of the } \\
\text { new venture, the } \\
\text { entrepreneur's social } \\
\text { capital, and the } \\
\text { firm performance } \\
\text { on the new } \\
\text { venture's knowledge } \\
\text { acquisition } \\
\text { activities. }\end{array}$ & $\begin{array}{l}\text { The means by } \\
\text { which new venture } \\
\text { founders incorporate } \\
\text { novel knowledge into } \\
\text { their organizations. }\end{array}$ & $\begin{array}{l}\text { Simulation } \\
\text { methodology, } \\
3 \text { runs in } 3 \\
\text { configurations. } \\
\text { Statistical } \\
\text { analysis, } \\
\text { regressions, } \\
\text { ANOVA, Post- } \\
\text { hoc Bonferroni } \\
\text { tests. }\end{array}$ & - & $\begin{array}{l}\text { Dependent: Regional } \\
\text { rate. } \\
\text { Independent: Level } \\
\text { of new venture } \\
\text { formation. }\end{array}$ & $\begin{array}{l}\text { The increase in the } \\
\text { firm's knowledge } \\
\text { diversity has } \\
\text { a positive impact } \\
\text { on the survival of } \\
\text { new ventures and } \\
\text { the sustainability of } \\
\text { entrepreneurship in } \\
\text { a region. }\end{array}$ & $\begin{array}{l}\text { To develop and } \\
\text { test more realistic } \\
\text { scenarios in the } \\
\text { simulation, and } \\
\text { qualitative and } \\
\text { quantitative } \\
\text { researches. }\end{array}$ \\
\hline $\begin{array}{l}\text { Mckelvie } \\
\text { et al. }\end{array}$ & 2018 & $\begin{array}{l}\text { ENTREPRENEURSHIP } \\
\text { THEORY AND } \\
\text { PRACTICE }\end{array}$ & $\begin{array}{l}\text { Empirical } \\
\text { article }\end{array}$ & $\begin{array}{l}\text { To address how } \\
\text { perceptional } \\
\text { difierences of } \\
\text { environmental } \\
\text { dynamism explain } \\
\text { differences between } \\
\text { external and } \\
\text { internal knowledge } \\
\text { development tor } \\
\text { the continuous } \\
\text { innovative efforts in } \\
\text { new ventures. }\end{array}$ & $\begin{array}{l}\text { The ability of a firm } \\
\text { to acquire new } \\
\text { knowledge. }\end{array}$ & $\begin{array}{l}\text { Survey, } \\
\text { Harmon's } \\
\text { one-factor test. } \\
\text { Hierarchical } \\
\text { linear } \\
\text { regression, } \\
\text { correlations, } \\
\text { and robustness } \\
\text { test. }\end{array}$ & $\begin{array}{l}316 \text { new } \\
\text { ventures in the } \\
\text { TIME sector in } \\
\text { Sweden. }\end{array}$ & $\begin{array}{l}\text { Dependent: New } \\
\text { venture innovation. } \\
\text { Independent: } \\
\text { External market } \\
\text { knowledge } \\
\text { acquisition. } \\
\text { Internal knowledge } \\
\text { generation. Market } \\
\text { dynamism and } \\
\text { Technological } \\
\text { dynamism. }\end{array}$ & $\begin{array}{l}\text { The newer ventures } \\
\text { invest in acquiring } \\
\text { knowledge from } \\
\text { the external } \\
\text { environment, the } \\
\text { more likely they are } \\
\text { to continue their } \\
\text { entrepreneurial } \\
\text { activities and } \\
\text { develop more new } \\
\text { products. New } \\
\text { ventures within } \\
\text { the same industrial } \\
\text { sector have different } \\
\text { perceptions about } \\
\text { the market and } \\
\text { technological } \\
\text { dynamism, these } \\
\text { perceptions are } \\
\text { important for } \\
\text { understanding } \\
\text { knowledge } \\
\text { development } \\
\text { processes. }\end{array}$ & $\begin{array}{l}\text { New studies using } \\
\text { a longitudinal or } \\
\text { panel a ppproach in } \\
\text { order to capture } \\
\text { temporal differences } \\
\text { in the elength of time. } \\
\text { Future researches } \\
\text { involving decision } \\
\text { making. }\end{array}$ \\
\hline Dai et al. & 2018 & $\begin{array}{l}\text { JOURNAL OF } \\
\text { MANAGEMENT } \\
\text { STUDIES }\end{array}$ & $\begin{array}{l}\text { Empirical } \\
\text { article }\end{array}$ & $\begin{array}{l}\text { To examine how new } \\
\text { ventures access and } \\
\text { use knowledge from } \\
\text { different external } \\
\text { sources, and gauge } \\
\text { the influence of } \\
\text { these efforts on their } \\
\text { strategic flexibility. }\end{array}$ & $\begin{array}{l}\text { A mechanism for } \\
\text { firms to acquire and } \\
\text { integrate diverse } \\
\text { and non- redundant } \\
\text { knowledge. }\end{array}$ & $\begin{array}{l}\text { Survey, ANOVA, } \\
\text { correlations, } \\
\text { multiple } \\
\text { regressions. } \\
\text { Aiken and } \\
\text { West's (1991) } \\
\text { procedure to } \\
\text { decompose } \\
\text { the interaction } \\
\text { terms. }\end{array}$ & $\begin{array}{l}148 \text { high-tech } \\
\text { ventures in the } \\
\text { Yangtze River } \\
\text { Delta, China. }\end{array}$ & $\begin{array}{l}\text { Dependent: Strategic } \\
\text { flexibility } \\
\text { Independent: } \\
\text { NPD alliances. } \\
\text { Loosely coupled } \\
\text { external sources of } \\
\text { knowledge. } \\
\text { Moderator: } \\
\text { Decentralization. } \\
\text { Institutional } \\
\text { support. }\end{array}$ & $\begin{array}{l}\text { In new ventures, } \\
\text { decentralization of } \\
\text { decision-making and } \\
\text { institutional support } \\
\text { enhances snowledge } \\
\text { integration. There } \\
\text { are } 2 \text { ways in which } \\
\text { new wigh-tech } \\
\text { ventures may } \\
\text { inmprove their } \\
\text { strategic flexibility: } \\
\text { by accessing } \\
\text { information and } \\
\text { knowledge, and } \\
\text { new product } \\
\text { development } \\
\text { alliancing. }\end{array}$ & $\begin{array}{l}\text { Further research } \\
\text { employing } \\
\text { a longitudinal design } \\
\text { with the use of } \\
\text { archival data. New } \\
\text { empirical studies } \\
\text { considering other } \\
\text { high-tech industries, } \\
\text { environments, and } \\
\text { characteristics. }\end{array}$ \\
\hline $\begin{array}{l}\text { Saemundsson } \\
\text { and Candi }\end{array}$ & 2017 & TECHNOVATION & $\begin{array}{l}\text { Empirical } \\
\text { article }\end{array}$ & $\begin{array}{l}\text { To investigate } \\
\text { relationships } \\
\text { between knowledge } \\
\text { and opportunities } \\
\text { in new ventures } \\
\text { and how potential } \\
\text { AC is related to the } \\
\text { identification of } \\
\text { opportunities in new } \\
\text { technology-based } \\
\text { firms (NTBFs). }\end{array}$ & $\begin{array}{l}\text { To acquire, assimilate } \\
\text { (potential AC). } \\
\text { transform and } \\
\text { exploit (realized } \\
\text { AC) knowledge for } \\
\text { innovation }\end{array}$ & $\begin{array}{l}\text { Survey collected } \\
\text { twice, one year } \\
\text { apart. Three- } \\
\text { step hierarchical } \\
\text { regression } \\
\text { analysis, } \\
\text { correlations, } \\
\text { Interaction } \\
\text { diagrams. }\end{array}$ & $\begin{array}{l}94 \text { NTBFs in } \\
\text { Northern } \\
\text { Europe }\end{array}$ & $\begin{array}{l}\text { Dependent: } \\
\text { Entrepreneurial } \\
\text { opportunities. } \\
\text { Independent: } \\
\text { Problem absorptive } \\
\text { capacity. Solution } \\
\text { absorptive capacity. }\end{array}$ & $\begin{array}{l}\text { Changes in problem } \\
\text { AC were a stronger } \\
\text { trigger for new } \\
\text { opportunities } \\
\text { identification } \\
\text { than changes in } \\
\text { solution AC. }\end{array}$ & $\begin{array}{l}\text { More work is } \\
\text { needed to improve } \\
\text { measures of } \mathrm{AC} \text { and } \\
\text { to better understand } \\
\text { the sources of the } \\
\text { solution, problem } \\
\text { and realized AC. }\end{array}$ \\
\hline
\end{tabular}




\section{Innovation cluster}

\begin{tabular}{|c|c|c|c|c|c|c|c|c|c|c|}
\hline AUTHORS & YEAR & JOURNAL & TYPE & AIM OF RESEARCH & RELEVANCE OF AC & METHODOLOGY & SAMPLE & VARIABLES & FINDINGS & $\begin{array}{l}\text { FUTURE RESEARCH } \\
\text { AGENDA }\end{array}$ \\
\hline $\begin{array}{l}\text { Dushnitsky, } \\
\text { G; Lenox, MJ }\end{array}$ & 2005 & RESEARCH POLICY & $\begin{array}{l}\text { Empirical } \\
\text { article }\end{array}$ & $\begin{array}{l}\text { Do firms that invest } \\
\text { corporate venture } \\
\text { capital (cVC) } \\
\text { learn about and } \\
\text { appropriate new } \\
\text { technologies and } \\
\text { practices from those } \\
\text { ventures in which } \\
\text { they invest? }\end{array}$ & $\begin{array}{l}\text { The greater } \\
\text { a firm's AC, } \\
\text { the greater the } \\
\text { marginal impact } \\
\text { of CVC investment } \\
\text { on firm innovation } \\
\text { rates. } \\
\text { The greater } \\
\text { a firm's AC, the } \\
\text { greater a firm's } \\
\text { investment in } \\
\text { entrepreneurial } \\
\text { ventures will } \\
\text { impact the firm's } \\
\text { innovation rate. }\end{array}$ & $\begin{array}{l}\text { Longitudinal panel } \\
\text { study }\end{array}$ & $\begin{array}{l}2289 \text { public firms that } \\
\text { invested corporate } \\
\text { venture capital or } \\
\text { patented during } \\
1969-1999 .\end{array}$ & $\begin{array}{l}\text { DV: patent } \\
\text { citations, IV: R\&D } \\
\text { Expenditures, } \\
\text { negative binomial } \\
\text { specification } \\
\text { with the firm, } \\
\text { sector, and year } \\
\text { fixed and random } \\
\text { effects and lagged } \\
\text { independent } \\
\text { variables. }\end{array}$ & $\begin{array}{l}\text { The authors found } \\
\text { that increases in } \\
\text { CCC investment } \\
\text { are associated } \\
\text { with subsequent } \\
\text { increases in future } \\
\text { citation-weighted } \\
\text { patenting rates. } \\
\text { furthermore. the } \\
\text { magnitude of this } \\
\text { effect depends } \\
\text { on the firm's AC } \\
\text { and the strength } \\
\text { of intellectual } \\
\text { property } \\
\text { protection. }\end{array}$ & $\begin{array}{l}\text { Future studies using } \\
\text { other measures of } \\
\text { AC (such as RR\&D } \\
\text { expenditure). }\end{array}$ \\
\hline $\begin{array}{l}\text { Dushnitsky, } \\
\text { G; Lenox, MJ }\end{array}$ & 2005 & $\begin{array}{l}\text { STRATEGIC } \\
\text { MANAGEMENT } \\
\text { JOURNAL }\end{array}$ & $\begin{array}{l}\text { Empirical } \\
\text { article }\end{array}$ & $\begin{array}{l}\text { What are the } \\
\text { conditions in which } \\
\text { firms are likely } \\
\text { to pursue equity } \\
\text { investment in new } \\
\text { ventures as a way } \\
\text { to source innovative } \\
\text { ideas? }\end{array}$ & $\begin{array}{l}\text { The greater } \\
\text { a firm's cash flow } \\
\text { and AC, the more } \\
\text { likely it is to invest } \\
\text { in new ventures. }\end{array}$ & $\begin{array}{l}\text { Longitudinal panel } \\
\text { study }\end{array}$ & $\begin{array}{l}1171 \text { U.S. public firms } \\
\text { during the period } \\
1990-1999 \\
60,444 \text { firm-year- } \\
\text { sector observation. }\end{array}$ & 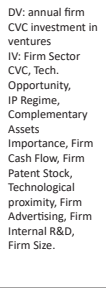 & $\begin{array}{l}\text { Ventures in } \\
\text { industries with } \\
\text { weak intellectual } \\
\text { ppoperty } \\
\text { protection } \\
\text { and where } \\
\text { complementary } \\
\text { distribution } \\
\text { capability is } \\
\text { important are } \\
\text { more tikely to } \\
\text { receive CVC. Cash } \\
\text { flow has a positive } \\
\text { effect on equity } \\
\text { investment. Firms } \\
\text { with greater AC } \\
\text { are more likely } \\
\text { to invest in new } \\
\text { ventures. }\end{array}$ & $\begin{array}{l}\text { Further researches } \\
\text { aiming to analyze } \\
\text { the latent } \\
\text { interdependencies } \\
\text { among the innovation } \\
\text { strategies (e.g. internal } \\
\text { R\&D and CVC). }\end{array}$ \\
\hline $\begin{array}{l}\text { Wadhwa, } \mathrm{A} \text {; } \\
\text { Kotha, } \mathrm{S}\end{array}$ & 2006 & $\begin{array}{l}\text { ACADEMY OF } \\
\text { MANAGEMENT } \\
\text { JOURNAL }\end{array}$ & $\begin{array}{l}\text { Empirical } \\
\text { article }\end{array}$ & $\begin{array}{l}\text { The study } \\
\text { investigated } \\
\text { the conditions } \\
\text { under which CVC } \\
\text { investments affect } \\
\text { knowledge creation } \\
\text { for corporate } \\
\text { investors. What } \\
\text { are the limits } \\
\text { to knowledge } \\
\text { creation from CVC } \\
\text { investments? } \\
\text { And when are } \\
\text { these limits likely to } \\
\text { manifest? }\end{array}$ & $\begin{array}{l}\text { Access to new } \\
\text { information } \\
\text { through CvC } \\
\text { improves the AC. } \\
\text { However, there } \\
\text { are limits to the } \\
\text { amount of new } \\
\text { knowledge that } \\
\text { an investment } \\
\text { company can } \\
\text { absorb. }\end{array}$ & $\begin{array}{l}\text { Longitudinal panel } \\
\text { study }\end{array}$ & $\begin{array}{l}\text { Telecommunications } \\
\text { equipment } \\
\text { manufacturing industry } \\
\text { between } \\
1989 \text { - } 999 \text {, and } \\
\text { Venture Xpert, the } \\
\text { official database of } \\
\text { the National Venture } \\
\text { Capital Association } \\
36 \text { corporate entities } \\
383 \text { firm-year } \\
\text { observations. }\end{array}$ & $\begin{array}{l}\text { DV: successful } \\
\text { patent } \\
\text { applications for } \\
\text { a firm in a year. } \\
\text { IV: : number of } \\
\text { cVC investments; } \\
\text { corporate } \\
\text { investor's } \\
\text { involvement; } \\
\text { technological } \\
\text { knowledge } \\
\text { diversity } \\
\text { CV: prior joint } \\
\text { ventures, } \\
\text { alliances, and } \\
\text { mergers and } \\
\text { acquisitions; } \\
\text { prior patent stock } \\
\text { of firm; firm } \\
\text { age, knowledge } \\
\text { relatedness } \\
\text { between the } \\
\text { investor and } \\
\text { portfolio firms; } \\
\text { the number } \\
\text { of venture } \\
\text { capitalists. }\end{array}$ & $\begin{array}{l}\text { When investor } \\
\text { involvement is } \\
\text { low, the number of } \\
\text { cVC investments } \\
\text { has an ininerted } \\
\text { U-shaped } \\
\text { relationship } \\
\text { with innovavion } \\
\text { performance. } \\
\text { When investor } \\
\text { involvement } \\
\text { is high, the } \\
\text { relationship } \\
\text { reverses, and } \\
\text { an increase in } \\
\text { investments } \\
\text { boosts innovation. }\end{array}$ & $\begin{array}{l}\text { Investigate other } \\
\text { industries; examine why } \\
\text { technological diversity } \\
\text { did not moderate the } \\
\text { relatitionship between } \\
\text { CVC investments and } \\
\text { innovation. }\end{array}$ \\
\hline $\begin{array}{l}\text { Filatotchev, } \\
\text { l; Liu, XH; } \\
\text { Lu, YH; } \\
\text { Wright, M }\end{array}$ & 2011 & RESEARCH POLICY & $\begin{array}{l}\text { Empirical } \\
\text { article }\end{array}$ & $\begin{array}{l}\text { What is the } \\
\text { impact of returnee } \\
\text { entrepreneurs and } \\
\text { their knowledge } \\
\text { spillovers on } \\
\text { innovation in high- } \\
\text { tech firms in China? }\end{array}$ & $\begin{array}{l}\text { AC moderates } \\
\text { the innovation } \\
\text { promoted } \\
\text { by returnee } \\
\text { entrepreneurs. }\end{array}$ & $\begin{array}{l}\text { Longitudinal panel } \\
\text { study }\end{array}$ & $\begin{array}{l}1318 \text { high-tech firms in } \\
\text { Beijing Zhongguancun } \\
\text { Science Park between } \\
2000-2003\end{array}$ & $\begin{array}{l}\text { DV: The number } \\
\text { of patents per } \\
\text { employee of } \\
\text { the firm; the } \\
\text { proportion of } \\
\text { sales from new } \\
\text { products new } \\
\text { VR: Skill intensity; } \\
\text { Returnee } \\
\text { spillovers; MNEs' } \\
\text { R\&Q activities } \\
\text { CV: In-house R\&D; } \\
\text { firm age; firm } \\
\text { size; ; wnership; } \\
\text { export intensity; } \\
\text { imported } \\
\text { technology; } \\
\text { industry \& } \\
\text { intensity }\end{array}$ & $\begin{array}{l}\text { Returnee } \\
\text { entrepreneurs } \\
\text { create a significant } \\
\text { spillover effect } \\
\text { that promotes } \\
\text { innovation in } \\
\text { other local high- } \\
\text { tech firms that } \\
\text { is moderated by } \\
\text { the non-returnee } \\
\text { firm's AC. }\end{array}$ & $\begin{array}{l}\text { To compare the efficacy } \\
\text { of the knowledge } \\
\text { brought by returnee } \\
\text { entrepreneurs } \\
\text { versus the resources } \\
\text { and knowledge } \\
\text { of multinational } \\
\text { enterprises in } \\
\text { stimulating the } \\
\text { development of } \\
\text { emerging economies. }\end{array}$ \\
\hline $\begin{array}{l}\text { McAdam, M; } \\
\text { McAdam, } \mathrm{R}_{;} \\
\text {Galbraith, B; } \\
\text { Miller, } \mathrm{K}\end{array}$ & 2010 & $\begin{array}{l}R \& D \\
\text { MANAGEMENT }\end{array}$ & $\begin{array}{l}\text { Empirical } \\
\text { article }\end{array}$ & $\begin{array}{l}\text { What is the role } \\
\text { and influence of the } \\
\text { Principal Investigator } \\
\text { (PI) in the Proof } \\
\text { of Concept (PoC) } \\
\text { process within } \\
\text { a University Science } \\
\text { Park Incubator } \\
\text { setting using an ACAP } \\
\text { perspective. }\end{array}$ & $\begin{array}{l}\text { How organizations } \\
\text { acquire new } \\
\text { knowledge } \\
\text { and leverage } \\
\text { it to achieve } \\
\text { a competitive } \\
\text { advantage. }\end{array}$ & $\begin{array}{l}\text { Multiple case } \\
\text { analysis of PoC; } \\
\text { interpretive } \\
\text { research } \\
\text { philosophy. }\end{array}$ & UK university projects & - & $\begin{array}{l}\text { PIs had good } \\
\text { technical } \\
\text { knowledge } \\
\text { and ideas for } \\
\text { applications but } \\
\text { were lacking } \\
\text { in commercial } \\
\text { awareness } \\
\text { and business } \\
\text { realitis. This lack } \\
\text { of commercial } \\
\text { awareness was } \\
\text { found to be the } \\
\text { most significant } \\
\text { challenge to to } \\
\text { increasing ACAP } \\
\text { within the USI } \\
\text { through the } \\
\text { stakeholders using } \\
\text { the PoC's routines } \\
\text { and practices. }\end{array}$ & $\begin{array}{l}\text { Mostly managerial } \\
\text { recommendations, } \\
\text { such as the suggestion } \\
\text { that rules regarding } \\
\text { ownership of patents } \\
\text { and licenses should } \\
\text { have more clarification } \\
\text { to increase the } \\
\text { entrepreneurial } \\
\text { motivation of the PI's. }\end{array}$ \\
\hline
\end{tabular}




\begin{tabular}{|c|c|c|c|c|c|c|c|c|c|c|}
\hline AUTHORS & YEAR & JOURNAL & TYPE & AIM OF RESEARCH & RELEVANCE OF AC & METHODOLOGY & SAMPLE & VARIABLES & FINDINGS & $\begin{array}{l}\text { FUTURE RESEARCH } \\
\text { AGENDA }\end{array}$ \\
\hline $\begin{array}{l}\text { Winkelbach, } \\
\text { A; Walter, A }\end{array}$ & 2015 & $\begin{array}{l}\text { INDUSTRIAL } \\
\text { MARKETING } \\
\text { MANAGEMENT }\end{array}$ & $\begin{array}{l}\text { Empirical } \\
\text { article }\end{array}$ & $\begin{array}{l}\text { What is the interplay } \\
\text { between } A C, \text { prior } \\
\text { knowledge, and value } \\
\text { creation. }\end{array}$ & $\begin{array}{l}\text { AC moderates } \\
\text { the interplay } \\
\text { between complex } \\
\text { knowledge and } \\
\text { value creation. } \\
\text { ACAP = prior } \\
\text { technological } \\
\text { knowledge. }\end{array}$ & $\begin{array}{l}\text { Survey. } \\
\text { Moderated } \\
\text { hierarchical } \\
\text { regression. }\end{array}$ & $\begin{array}{l}\text { Database of } 127 \\
\text { science-to-industry } \\
\text { R\&D projects in } \\
\text { technology-based } \\
\text { markets. }\end{array}$ & $\begin{array}{l}\text { DV: transfer value } \\
\text { IV: knowledge } \\
\text { attribute } \\
\text { complexity, prior } \\
\text { knowledge, } \\
\text { absorptive } \\
\text { capabilities, } \\
\text { absorptive } \\
\text { capabilities } \\
\text { CV: tie streneth, } \\
\text { prior partnership } \\
\text { experience, } \\
\text { and structural } \\
\text { characteristics. }\end{array}$ & $\begin{array}{l}\text { Prior knowledge } \\
\text { has no significant } \\
\text { effect on value } \\
\text { creation per } \\
\text { se. Instead, the } \\
\text { impact of complex } \\
\text { technological } \\
\text { knowledge on } \\
\text { value creation is } \\
\text { enhanced at high } \\
\text { levels of both } \\
\text { prior knowledge } \\
\text { and absorptive } \\
\text { capabilitities. }\end{array}$ & 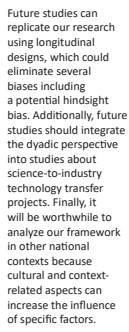 \\
\hline $\begin{array}{l}\text { McAdam, } \mathrm{R} ; \\
\text { McAdam, M; } \\
\text { Brown, } \mathrm{V}\end{array}$ & 2009 & $\begin{array}{l}\text { R\& D } \\
\text { MANAGEMENT }\end{array}$ & $\begin{array}{l}\text { Empirical } \\
\text { article }\end{array}$ & $\begin{array}{l}\text { To explore the Proof } \\
\text { of Concept (PoC) } \\
\text { process within } \\
\text { a University Science } \\
\text { Park Incubator } \\
\text { as a means for } \\
\text { improving the } \\
\text { commercialization of } \\
\text { University technology } \\
\text { transfer using an AC } \\
\text { perspective. }\end{array}$ & $\begin{array}{l}\text { Importance } \\
\text { of Absorptive } \\
\text { Capacity on PoC } \\
\text { outcomes. }\end{array}$ & $\begin{array}{l}\text { Multiple case } \\
\text { analysis; } \\
\text { interpretive } \\
\text { research } \\
\text { philosophy; } \\
\text { semi-structured } \\
\text { interviews. }\end{array}$ & 16 PoC projects; & - & $\begin{array}{l}\text { AC influencing } \\
\text { factors such as } \\
\text { levels of R\&D } \\
\text { investment, prior } \\
\text { knowledge base, } \\
\text { and integration } \\
\text { of stakeholder } \\
\text { and technology } \\
\text { planning which } \\
\text { impact the PoC } \\
\text { outcomes. }\end{array}$ & $\begin{array}{l}\text { Mostly managerial } \\
\text { recommendations, such } \\
\text { as outsourcing some } \\
\text { include more post PoC } \\
\text { planning measures } \\
\text { or programs aiming } \\
\text { commercialization. }\end{array}$ \\
\hline Marvel, M & 2012 & $\begin{array}{l}\text { JOURNAL OF } \\
\text { SMALL BUSINESS } \\
\text { MANAGEMENT }\end{array}$ & $\begin{array}{l}\text { Empirical } \\
\text { article }\end{array}$ & $\begin{array}{l}\text { Explore knowledge } \\
\text { acquisition } \\
\text { asymmetries in early } \\
\text { venture development } \\
\text { and how they are } \\
\text { related to innovation } \\
\text { creation. }\end{array}$ & $\begin{array}{l}\text { AC as a control } \\
\text { variable: } \\
\text { aspects of prior } \\
\text { knowledge and } \\
\text { experience may } \\
\text { relate to Ac and } \\
\text { the development } \\
\text { of fadidal } \\
\text { offerings. }\end{array}$ & Survey & $\begin{array}{l}166 \text { founders of new } \\
\text { technology ventures in } \\
\text { university incubators }\end{array}$ & $\begin{array}{l}\text { IV: Knowledge } \\
\text { Acquisition. } \\
\text { DV Il Inovation } \\
\text { Radicalness. } \\
\text { Control Variables: } \\
\text { nature of the } \\
\text { venture's offering, } \\
\text { experiencec depth, } \\
\text { formal education, } \\
\text { experience } \\
\text { breadth, and } \\
\text { physical sciences/ } \\
\text { engineering } \\
\text { education. }\end{array}$ & $\begin{array}{l}\text { Asymmetries } \\
\text { in knowledge } \\
\text { acquistition during } \\
\text { early venture } \\
\text { develoment are } \\
\text { vital to innovation } \\
\text { creation. } \\
\text { Innovation } \\
\text { radicalness } \\
\text { was positively } \\
\text { associated } \\
\text { with hacquiring } \\
\text { knowledge } \\
\text { of customer } \\
\text { problems and } \\
\text { markets. } \\
\text { Aqquiring } \\
\text { knowledge of ways } \\
\text { to serve markets } \\
\text { was negatively } \\
\text { associated with } \\
\text { innovation } \\
\text { radicalness. The } \\
\text { fewer technology } \\
\text { entrepreneurs } \\
\text { know about } \\
\text { comparable } \\
\text { offerings in the } \\
\text { market and } \\
\text { how to develop } \\
\text { them, the greater } \\
\text { their chances } \\
\text { of creating } \\
\text { breakthrough } \\
\text { innovations. }\end{array}$ & $\begin{array}{l}\text { Future studies are } \\
\text { encouraged to explore } \\
\text { the multidimensional } \\
\text { nature of knowledge } \\
\text { and learning in } \\
\text { explaining opportunity } \\
\text { discovery, exploitation, } \\
\text { and venture outcomes }\end{array}$ \\
\hline $\begin{array}{l}\text { Monferrer, } \\
\text { D; Blessa, } A ; \\
\text { Ripolles, } M\end{array}$ & 2015 & $\begin{array}{l}\text { EUROPEAN } \\
\text { JOURNAL OF } \\
\text { INTERATIONAL } \\
\text { MANAGEMENT }\end{array}$ & $\begin{array}{l}\text { Empirical } \\
\text { article }\end{array}$ & $\begin{array}{l}\text { How market- } \\
\text { orientated networks } \\
\text { contribute to the } \\
\text { development of } \\
\text { adaptive, absorptive, } \\
\text { and innovative } \\
\text { knowledge-based } \\
\text { dynamic capabilities } \\
\text { in international new } \\
\text { ventures (INV)? } \\
\text { (market orientation is } \\
\text { defined as a strategic } \\
\text { orientation } \\
\text { established jointly } \\
\text { by the different } \\
\text { members in the } \\
\text { business relations } \\
\text { network) }\end{array}$ & $\begin{array}{l}\text { The participation } \\
\text { of INVs in market- } \\
\text { oriented networks } \\
\text { encourages } \\
\text { their AC. } \\
\text { Network market } \\
\text { orientation makes } \\
\text { a significant } \\
\text { contributiton to } \\
\text { the development } \\
\text { of AC in INVs. }\end{array}$ & $\begin{array}{l}\text { Survey; structural } \\
\text { equations } \\
\text { modeling }\end{array}$ & $\begin{array}{l}303 \text { firms founded } \\
\text { after } 2005 \text { and with } \\
\text { international activity }\end{array}$ & $\begin{array}{l}\text { Variables: market } \\
\text { orientation of } \\
\text { the network } \\
\text { and dynamic } \\
\text { capabilities of } \\
\text { the firms }\end{array}$ & $\begin{array}{l}\text { The study shows } \\
\text { the utility of the } \\
\text { network market } \\
\text { orientation } \\
\text { construct. } \\
\text { Knowledge } \\
\text { derived from the } \\
\text { firm's market- } \\
\text { oriented networks, } \\
\text { helps the firms to } \\
\text { develop dynamic } \\
\text { capabilities in } \\
\text { order to act } \\
\text { sustainably in } \\
\text { their international } \\
\text { markets. }\end{array}$ & $\begin{array}{l}\text { Future studies that } \\
\text { continue to analyze } \\
\text { factors that can explain } \\
\text { the international } \\
\text { comperitiveness } \\
\text { of INVs. }\end{array}$ \\
\hline $\begin{array}{l}\text { Kamuriwo, } \\
\text { DS; Baden- } \\
\text { Fuller, C; } \\
\text { Zhang, } j\end{array}$ & 2017 & $\begin{array}{l}\text { JOURNAL OF } \\
\text { PRODUCT } \\
\text { INNOVATION } \\
\text { MANAGEMENT }\end{array}$ & $\begin{array}{l}\text { Empirical } \\
\text { article }\end{array}$ & $\begin{array}{l}\text { What are the } \\
\text { coordination } \\
\text { mechanisms, models, } \\
\text { and approaches that } \\
\text { are most effective } \\
\text { at producing } \\
\text { breakthrough } \\
\text { innovations? }\end{array}$ & $\begin{array}{l}\text { Search capabilities } \\
\text { and AC of } \\
\text { partners can be } \\
\text { used when TBNF's } \\
\text { are undertaking } \\
\text { fundamental } \\
\text { research. }\end{array}$ & $\begin{array}{l}\text { Longitudinal panel } \\
\text { study }\end{array}$ & $\begin{array}{l}69 \text { UK new } \\
\text { biotechnology firms } \\
\text { over } 11 \text { years. }\end{array}$ & $\begin{array}{l}\text { DV: number of the } \\
\text { firm's patents that } \\
\text { turned out to be } \\
\text { a breakthrough } \\
\text { innovation; } \\
\text { product } \\
\text { development rate } \\
\text { IV: Knowledge } \\
\text { development } \\
\text { mode. } \\
\text { CV: funds, vc } \\
\text { backing, vublic } \\
\text { stock listing, } \\
\text { number of } \\
\text { employees, } \\
\text { number of } \\
\text { alliances, } \\
\text { technology type, } \\
\text { therapeutic } \\
\text { categories }\end{array}$ & $\begin{array}{l}\text { External } \\
\text { knowledge- } \\
\text { development } \\
\text { mode is associated } \\
\text { with more } \\
\text { breakthrough } \\
\text { innovations and } \\
\text { a faster movement } \\
\text { of innovations to } \\
\text { market. }\end{array}$ & $\begin{array}{l}\text { Future studies will need } \\
\text { to model the firms' } \\
\text { choice of knowledge } \\
\text { development modes } \\
\text { directly and the } \\
\text { antecedents to the } \\
\text { knowledge } \\
\text { development. }\end{array}$ \\
\hline
\end{tabular}




\begin{tabular}{|c|c|c|c|c|c|c|c|c|c|c|}
\hline AUTHORS & YEAR & JOURNAL & TYPE & AIM OF RESEARCH & RELEVANCE OF AC & METHODOLOGY & SAMPLE & VARIABLES & FINDINGS & $\begin{array}{l}\text { FUTURE RESEARCH } \\
\text { AGERDA }\end{array}$ \\
\hline $\begin{array}{l}\text { Lee, SM; Kim, } \\
\text { T; Jang, SH }\end{array}$ & 2015 & $\begin{array}{l}\text { MANAGEMENT } \\
\text { DECISION }\end{array}$ & $\begin{array}{l}\text { Empirical } \\
\text { article }\end{array}$ & $\begin{array}{l}\text { To identify the } \\
\text { circumstances } \\
\text { under which CvC } \\
\text { investment facilitates } \\
\text { knowledge transfer } \\
\text { from start-ups to } \\
\text { investing firms }\end{array}$ & $\begin{array}{l}\text { AC plays a critical } \\
\text { role in facilitating } \\
\text { knowledge } \\
\text { transfer across } \\
\text { organizations }\end{array}$ & $\begin{array}{l}\text { Longitudinal panel } \\
\text { study }\end{array}$ & $\begin{array}{l}29 \text { investor firms } \\
\text { that invested in } \\
\text { entrepreneurial firms } \\
\text { at least once during } \\
1995-2005\end{array}$ & 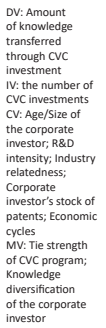 & $\begin{array}{l}\text { The relationship } \\
\text { between the } \\
\text { crvi investment } \\
\text { and the level } \\
\text { of knowledgee } \\
\text { transfer either } \\
\text { diminishes or } \\
\text { results in negative } \\
\text { returns. The } \\
\text { authors found out } \\
\text { that corporate } \\
\text { investors } \\
\text { need a proper } \\
\text { mechanism } \\
\text { of knowledge } \\
\text { transirer if they } \\
\text { are to maximize } \\
\text { the innovative } \\
\text { outcome of cVC } \\
\text { investment. }\end{array}$ & $\begin{array}{l}\text { Future studies analyzing } \\
\text { different regions and } \\
\text { different environmental } \\
\text { settings that may } \\
\text { influence the design of } \\
\text { cV c programs and their } \\
\text { effects on knowledge } \\
\text { transfer from the start. } \\
\text { up to the investing firm. } \\
\text { Additionally, a much } \\
\text { wider range of time } \\
\text { span should be used to } \\
\text { examine the effect of } \\
\text { cVC investment. }\end{array}$ \\
\hline
\end{tabular}

\section{Performance cluster}

\begin{tabular}{|c|c|c|c|c|c|c|c|c|c|c|}
\hline AUTHORS & YEAR & JOURNAL & TYPE & AIM OF RESEARCH & RELEVANCE OF AC & METHODOLOGY & SAMPLE & VARIABLES & FINDINGS & $\begin{array}{l}\text { FUTURE RESEARCH } \\
\text { AGENDA }\end{array}$ \\
\hline Witt, P & 2004 & $\begin{array}{l}\text { ENTREPRENEURSHIP } \\
\text { AND REGIONAL } \\
\text { DEVELOPMENT }\end{array}$ & $\begin{array}{l}\text { Conceptual } \\
\text { article }\end{array}$ & $\begin{array}{l}\text { How entrepreneurial } \\
\text { network activities } \\
\text { can be measured } \\
\text { and which indicators } \\
\text { exist to quantify } \\
\text { start-up success. } \\
\text { What is the } \\
\text { relationship between } \\
\text { entrepreneurial } \\
\text { networks and start- } \\
\text { up success. }\end{array}$ & $\begin{array}{l}\text { Networking abilitities } \\
\text { influence the } \\
\text { AC of founders. } \\
\text { Entrepreneurs will } \\
\text { not be able to benefit } \\
\text { from co-opoerations } \\
\text { and information from } \\
\text { network partners if } \\
\text { they do not possess } \\
\text { the necessary } \\
\text { knowledge and the } \\
\text { capacity to absorb the } \\
\text { information in their } \\
\text { own organization. }\end{array}$ & $\begin{array}{l}\text { Theoretical Essay } \\
\text { / Literature } \\
\text { Review }\end{array}$ & - & - & $\begin{array}{l}\text { The study reveals that } \\
\text { the major shortcomings } \\
\text { of existing network } \\
\text { studies are found to be } \\
\text { the neglect of different } \\
\text { starting conditions, } \\
\text { the focus on individual } \\
\text { founders' networks } \\
\text { instead of multiple } \\
\text { networks in start-ups } \\
\text { with an entrepreneurial } \\
\text { team, and the } \\
\text { asssumption of a linear } \\
\text { causal relation between } \\
\text { networking and start-up } \\
\text { success. }\end{array}$ & $\begin{array}{l}\text { Future research } \\
\text { studying the } \\
\text { dynamics of } \\
\text { networks, changes in } \\
\text { network utilization, } \\
\text { and measurable } \\
\text { definitions for the } \\
\text { different network } \\
\text { types. }\end{array}$ \\
\hline $\begin{array}{l}\text { Zahra, SA; } \\
\text { Hayton, JC }\end{array}$ & 2008 & $\begin{array}{l}\text { JOURNAL OF BUSINESS } \\
\text { VENTURING }\end{array}$ & $\begin{array}{l}\text { Empirical } \\
\text { article }\end{array}$ & $\begin{array}{l}\text { Does the } A C \\
\text { moderate the } \\
\text { relationship between } \\
\text { international } \\
\text { venturing } \\
\text { and company } \\
\text { performance? }\end{array}$ & $\begin{array}{l}\text { the importance of } \\
\text { AC for achieving } \\
\text { profitability and } \\
\text { growth over } \\
\text { international } \\
\text { acquisitions and } \\
\text { alliances. }\end{array}$ & $\begin{array}{l}\text { Hierarchical } \\
\text { regression } \\
\text { modeling }\end{array}$ & $\begin{array}{l}217 \text { global } \\
\text { manufacturing } \\
\text { firms }\end{array}$ & $\begin{array}{l}\text { DV: profitability } \\
\text { and revenue } \\
\text { growth IV } \\
\text { international } \\
\text { acquisitions and } \\
\text { international } \\
\text { alliances } \\
\text { moderated } \\
\text { by AC }\end{array}$ & $\begin{array}{l}\text { AC moderates the } \\
\text { relationship between } \\
\text { international venturing } \\
\text { and firms profitability } \\
\text { and revenue growth. }\end{array}$ & $\begin{array}{l}\text { It would be useful } \\
\text { to document the } \\
\text { various types of } \\
\text { knowledge a firm } \\
\text { might tain from } \\
\text { international } \\
\text { venturing and } \\
\text { the specific types } \\
\text { of knowledge } \\
\text { associated with } \\
\text { various approaches } \\
\text { to international } \\
\text { venturing }\end{array}$ \\
\hline Deeds, DL & 2001 & $\begin{array}{l}\text { JOURNAL OF } \\
\text { ENGINEERING } \\
\text { AND TECHNOLGGY } \\
\text { MANAGEMENT }\end{array}$ & $\begin{array}{l}\text { Empirical } \\
\text { article }\end{array}$ & $\begin{array}{l}\text { What is the } \\
\text { relationship between } \\
\text { a high technology } \\
\text { venture's R\&D } \\
\text { intensity, technical } \\
\text { capabilities and } A C ; \\
\text { and the amount } \\
\text { of entrepreneurial } \\
\text { wealth created by } \\
\text { the venture? }\end{array}$ & $\begin{array}{l}\text { AC is positively } \\
\text { related to the amount } \\
\text { of entrepreneurial } \\
\text { wealth created by the } \\
\text { venture. }\end{array}$ & $\begin{array}{l}\text { Longitudinal } \\
\text { panel study }\end{array}$ & $\begin{array}{l}80 \\
\text { pharmaceutical } \\
\text { biotechnology } \\
\text { companies, } \\
\text { which went } \\
\text { public between } \\
1982 \text { and } 1993\end{array}$ & $\begin{array}{l}\text { DV: MVA } \\
\text { (Market value } \\
\text { added) } \\
\text { IV: Research and } \\
\text { development } \\
\text { intensity; } \\
\text { Technical } \\
\text { developpent } \\
\text { capability; } \\
\text { Absorptive } \\
\text { capacity } \\
\text { Cv: Hot markets, } \\
\text { Number of } \\
\text { employees }\end{array}$ & $\begin{array}{l}\text { There is a positive } \\
\text { relationship between } \\
\text { a high technology } \\
\text { venture's R\&D intensity, } \\
\text { late stage technical } \\
\text { capabilities and } A C ; \\
\text { and the amount of } \\
\text { entrepreneurial wealth } \\
\text { created by a high } \\
\text { technology venture. }\end{array}$ & $\begin{array}{l}\text { Studies of } \\
\text { entrepreneurial } \\
\text { wealth creation in } \\
\text { other technology } \\
\text { and industry } \\
\text { contexts in } \\
\text { order to expand } \\
\text { understanding. } \\
\text { Further studies } \\
\text { about the } \\
\text { relationship } \\
\text { between the R\&D } \\
\text { intensity, technical } \\
\text { develop ment } \\
\text { capabilities and } \\
\text { AC, and other } \\
\text { measures of a high } \\
\text { technology venture's } \\
\text { performance, such } \\
\text { as survival, growth, } \\
\text { profitability, etc. }\end{array}$ \\
\hline $\begin{array}{l}\text { Benson, D; } \\
\text { Ziedonis, } \\
\mathrm{RH}\end{array}$ & 2009 & $\begin{array}{l}\text { ORGANIZATION } \\
\text { SCIENCE }\end{array}$ & $\begin{array}{l}\text { Empirical } \\
\text { article }\end{array}$ & $\begin{array}{l}\text { What are the } \\
\text { beneficial effects } \\
\text { of CVC investing } \\
\text { on acquisition } \\
\text { performance? }\end{array}$ & $\begin{array}{l}\text { Information gained } \\
\text { through cVc investing } \\
\text { can be useful, but } \\
\text { internal technological } \\
\text { capabilities remain } \\
\text { a critical determinant } \\
\text { of success in } \\
\text { innovation-driven } \\
\text { acquisitions. }\end{array}$ & $\begin{array}{l}\text { Longitudinal } \\
\text { panel study }\end{array}$ & $\begin{array}{l}34 \text { CVC investors } \\
\text { in the IT sector } \\
\text { that acquired } \\
\text { a total of } \\
27 \text { startups } \\
\text { between } 1987 \\
\text { and } 2003\end{array}$ & $\begin{array}{l}\text { DV: Acquisition } \\
\text { Performance } \\
\text { IV: CVC } \\
\text { Intensity, } \\
\text { Stability, } \\
\text { Consecutive } \\
\text { years investing } \\
\text { in CVC, Total } \\
\text { years investing } \\
\text { in CCC, } \\
\text { CV: } \\
\text { Characteristics } \\
\text { of the Acquirer, } \\
\text { Characteristics } \\
\text { of the Target } \\
\text { and the Deal }\end{array}$ & $\begin{array}{l}\text { As CVC investments } \\
\text { increase relative to an } \\
\text { acquirer's total R\&D } \\
\text { expenditures, acquisition } \\
\text { performance improves } \\
\text { at a diminishing rate. } \\
\text { Firms consistently } \\
\text { engaged in venture } \\
\text { financing earn greater } \\
\text { returns when acquiring } \\
\text { startups than do firms } \\
\text { with more sporadic } \\
\text { patterns of investing, } \\
\text { even controlling for firm } \\
\text { profitability, size, and } \\
\text { acquisition experience. }\end{array}$ & 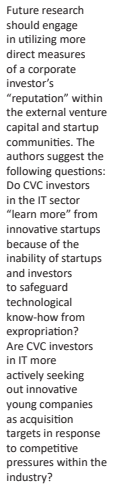 \\
\hline
\end{tabular}




\begin{tabular}{|c|c|c|c|c|c|c|c|c|c|c|}
\hline AUTHORS & YEAR & JOURNAL & TYPE & AIM OF RESEARCH & RELEVANCE OF AC & METHODOLOGY & SAMPLE & VARIABLES & FINDINGS & $\begin{array}{l}\text { FUTURE RESEARCH } \\
\text { AGENDA }\end{array}$ \\
\hline $\begin{array}{l}\text { Newey, LR; } \\
\text { Zahra, SA }\end{array}$ & 2009 & $\begin{array}{l}\text { BRITISH JOURNAL OF } \\
\text { MANAGEMENT }\end{array}$ & $\begin{array}{l}\text { Empirical } \\
\text { article }\end{array}$ & $\begin{array}{l}\text { How collaborating } \\
\text { companies use } \\
\text { A p processes at } \\
\text { operating and } \\
\text { dynamic apability } \\
\text { levels? }\end{array}$ & $\begin{array}{l}\text { The authors } \\
\text { propose } \mathrm{AC} \text { as a key } \\
\text { knowledge-based } \\
\text { mechanism linking } \\
\text { learning to product } \\
\text { development and } \\
\text { portfolio planning. }\end{array}$ & $\begin{array}{l}\text { Case study. } \\
\text { Interviews } \\
\text { with } 12 \text { key } \\
\text { informants }\end{array}$ & $\begin{array}{l}2 \text { biotech } \\
\text { companies }\end{array}$ & - & $\begin{array}{l}\text { At the operating } \\
\text { capability level, firms } \\
\text { build AC in value } \\
\text { networks during their } \\
\text { product development } \\
\text { experiences and this } \\
\text { learning needs to be } \\
\text { captured at the product } \\
\text { portfolio planning } \\
\text { level. Then, product } \\
\text { portfolion planning acts } \\
\text { as a dynamic capability } \\
\text { reconfiguring operating } \\
\text { capabilities based on } \\
\text { beliefs about follow-on } \\
\text { entrepreneurial } \\
\text { opportunities. } \\
\text { Under conditions of } \\
\text { endogenous change, } \\
\text { dynamicic capabilitites are } \\
\text { guided by a proactive } \\
\text { entrepreneurial } \\
\text { logic, complementing } \\
\text { the need for reactive } \\
\text { adaptive responses in } \\
\text { circumstances of the } \\
\text { exogenous change. }\end{array}$ & 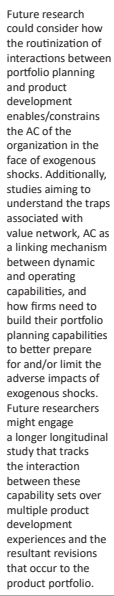 \\
\hline $\begin{array}{l}\text { Clarysse, } \\
\text { B; Wright, } \\
\text { M; Van de } \\
\text { velde, E }\end{array}$ & 2011 & $\begin{array}{l}\text { JOURNAL OF } \\
\text { MANAGEMENT } \\
\text { STUDIES }\end{array}$ & $\begin{array}{l}\text { Empirical } \\
\text { article }\end{array}$ & $\begin{array}{l}\text { How different } \\
\text { characteristics in } \\
\text { the technological } \\
\text { knowledge } \\
\text { base at start-up } \\
\text { influence spin-off } \\
\text { performance? }\end{array}$ & $\begin{array}{l}\text { Importance of the } \\
\text { knowledge in the } \\
\text { same domain as the } \\
\text { parent (university/ } \\
\text { corporate) for spin- } \\
\text { off's srowth. }\end{array}$ & $\begin{array}{l}\text { Longitudinal } \\
\text { panel study }\end{array}$ & $\begin{array}{l}48 \text { corporate } \\
\text { and } 73 \\
\text { university spin- } \\
\text { offs, comprising } \\
\text { the population } \\
\text { of spin-offs in } \\
\text { Flanders during } \\
\text { 1991-2002. }\end{array}$ & $\begin{array}{l}\text { DV: venture } \\
\text { growth } \\
\text { IV: Scope, } \\
\text { Newness, } \\
\text { Tacitness, } \\
\text { Relatedness } \\
\text { CV: firm age, } \\
\text { number of } \\
\text { employees, } \\
\text { start-up capital } \\
\text { of the spin-off, } \\
\text { technological } \\
\text { domain } \\
\text { (industry) }\end{array}$ & $\begin{array}{l}\text { Corporate spin-offs grow } \\
\text { most if theystart with } \\
\text { a specific narrow- } \\
\text { focusued technology } \\
\text { sufficiently distinct from } \\
\text { the technical knowledge } \\
\text { base of the parent } \\
\text { company and which } \\
\text { is tacit. } \\
\text { The novelty of technical } \\
\text { knowledge does not play } \\
\text { a role in corporate spin- } \\
\text { offs but has a negative } \\
\text { impact on university } \\
\text { spin-offs unless } \\
\text { universities have an } \\
\text { experienced technology } \\
\text { transfer office to support } \\
\text { the spin-off. }\end{array}$ & $\begin{array}{l}\text { Expand the } \\
\text { research to other } \\
\text { geographical regions, } \\
\text { incorporating } \\
\text { different institutional } \\
\text { contexts conduct } \\
\text { a longitudinal design } \\
\text { detailing the changes } \\
\text { in the scope of } \\
\text { technology; research } \\
\text { the role of social } \\
\text { capital and networks } \\
\text { provided by the } \\
\text { parent organization } \\
\text { or considered } \\
\text { the nature of the } \\
\text { relationship with the } \\
\text { parent organization. }\end{array}$ \\
\hline $\begin{array}{l}\text { Wales, WJ; } \\
\text { Parida, V; } \\
\text { Patel, PC }\end{array}$ & 2013 & $\begin{array}{l}\text { STRATEGIC } \\
\text { MANAGEMENT } \\
\text { JOURNAL }\end{array}$ & $\begin{array}{l}\text { Empirical } \\
\text { article }\end{array}$ & $\begin{array}{l}\text { What is the nature } \\
\text { of the relationship } \\
\text { between ACAP } \\
\text { and financial } \\
\text { performance? }\end{array}$ & $\begin{array}{l}\text { AC } \times \text { Financial } \\
\text { performance } \\
\text { trade-off }\end{array}$ & $\begin{array}{l}\text { Survey. one-factor } \\
\text { analysis }\end{array}$ & $\begin{array}{l}285 \text { Swedish } \\
\text { small-to } \\
\text { medium-sized } \\
\text { enterprises }\end{array}$ & $\begin{array}{l}\text { DV: growth } \\
\text { IV: ACAP, EO } \\
\text { CV: Firm } \\
\text { age, size, } \\
\text { productivity } \\
\text { growth, equity } \\
\text { ownership, } \\
\text { geographical } \\
\text { focus, market } \\
\text { sector }\end{array}$ & $\begin{array}{l}\text { There is indirect } \\
\text { evidence associated } \\
\text { with ACAP that produces } \\
\text { an inverted U-shaped } \\
\text { relationship with } \\
\text { financial performance } \\
\text { and that Entrepreneurial } \\
\text { Orientation (EO) may } \\
\text { enhance returns to } \\
\text { investments in ACAP. }\end{array}$ & $\begin{array}{l}\text { Research on other } \\
\text { industry yectors; } \\
\text { studies making } \\
\text { a direct cost } \\
\text { measure. }\end{array}$ \\
\hline $\begin{array}{l}\text { Simsek, }, \text {; } \\
\text { Heavey, C }\end{array}$ & 2011 & $\begin{array}{l}\text { STRATEGIC } \\
\text { ENTREPRENEURSHIP } \\
\text { JOURNAL }\end{array}$ & $\begin{array}{l}\text { Empirical } \\
\text { article }\end{array}$ & $\begin{array}{l}\text { How corporate } \\
\text { entrepreneurship } \\
\text { (CE) contributes to } \\
\text { extending the firm's } \\
\text { knowledge-based } \\
\text { capital and its } \\
\text { performance. }\end{array}$ & $\begin{array}{l}\text { CE enables ACAP of } \\
\text { SME enterprises. } \\
\text { CE governs firm } \\
\text { performance as } \\
\text { a dynamic capability } \\
\text { by reconfiguring, } \\
\text { extending, and } \\
\text { modifying the firm's } \\
\text { knowledge-based } \\
\text { resources }\end{array}$ & $\begin{array}{l}\text { Survey. } \\
\text { Confirmatory } \\
\text { factor analysis } \\
\text { to validate the } \\
\text { scales; cross- } \\
\text { sectional design }\end{array}$ & $\begin{array}{l}\text { TMTs of } 125 \\
\text { firms }\end{array}$ & $\begin{array}{l}\text { DV: Firm } \\
\text { performance } \\
\text { IV: the firm's } \\
\text { pursuit of CE } \\
\text { (firm's pursuit } \\
\text { of innovation, } \\
\text { venturing, } \\
\text { and strategic } \\
\text { renewal); } \\
\text { Knowledge- } \\
\text { based capital } \\
\text { (human, } \\
\text { social and } \\
\text { organizational } \\
\text { capital) }\end{array}$ & $\begin{array}{l}\text { The pursuit of CE } \\
\text { enhances the firm's } \\
\text { knowledge-based } \\
\text { capital residing in } \\
\text { people (human capital), } \\
\text { relationships (social } \\
\text { capitial), and systems } \\
\text { (organizational capital). } \\
\text { CE is mediated by } \\
\text { capital type. }\end{array}$ & $\begin{array}{l}\text { Other studies } \\
\text { examining CE effects } \\
\text { and the mediator } \\
\text { role of knowledge- } \\
\text { based mechanisms } \\
\text { and performance. }\end{array}$ \\
\hline $\begin{array}{l}\text { Zheng, } \\
\text { YF; Liu, J; } \\
\text { George, G }\end{array}$ & 2010 & $\begin{array}{l}\text { JOURNAL OF BUSINESS } \\
\text { VENTURING }\end{array}$ & $\begin{array}{l}\text { Empirical } \\
\text { article }\end{array}$ & $\begin{array}{l}\text { How do the effects of } \\
\text { innovative capability } \\
\text { and inter-firm } \\
\text { network attributes } \\
\text { on valuation vary } \\
\text { with firm age? }\end{array}$ & $\begin{array}{l}\text { A heterogeneneous } \\
\text { network provides } \\
\text { access to diverse } \\
\text { and effective } \\
\text { information flows and, } \\
\text { consequently, provides } \\
\text { the opportunity } \\
\text { to absorb external } \\
\text { information. ACAP is } \\
\text { positivily influenced } \\
\text { by a heterogeneous } \\
\text { network. }\end{array}$ & $\begin{array}{l}\text { Longitudinal } \\
\text { panel study }\end{array}$ & $\begin{array}{l}170 \\
\text { biotechnology } \\
\text { start-ups }\end{array}$ & $\begin{array}{l}\text { DV: Firm } \\
\text { valuation } \\
\text { IV: Innovative } \\
\text { capability } \\
\text { CV: Market } \\
\text { condition, } \\
\text { Biotech firm } \\
\text { density, } \\
\text { Geographic } \\
\text { area, } \\
\text { Technological } \\
\text { field, Public } \\
\text { company, Total } \\
\text { alliances, Equity } \\
\text { alliances }\end{array}$ & $\begin{array}{l}\text { The relative value of } \\
\text { network status seclines } \\
\text { while the impact of } \\
\text { innovative capability } \\
\text { increases with firm } \\
\text { age. Furthermore, } \\
\text { there is a growing } \\
\text { complementary effect of } \\
\text { innovative capability and } \\
\text { network heterogeneity } \\
\text { on firm valuation. }\end{array}$ & $\begin{array}{l}\text { The authors suggest } \\
\text { the following } \\
\text { questions: What } \\
\text { happens to the } \\
\text { effects on firm } \\
\text { valuation in the } \\
\text { long run? Does } \\
\text { the capability/ } \\
\text { network effect reach } \\
\text { a plateaue effect } \\
\text { after increasing } \\
\text { or declining when } \\
\text { routine development } \\
\text { and information } \\
\text { accumulation reach } \\
\text { their equilibrium } \\
\text { stage when } \\
\text { new routines } \\
\text { or information } \\
\text { contribute little to } \\
\text { firm value? or do } \\
\text { firm capabilitites } \\
\text { undergo a life } \\
\text { cycle with periods } \\
\text { of growth and } \\
\text { decline? }\end{array}$ \\
\hline
\end{tabular}




\begin{tabular}{|c|c|c|c|c|c|c|c|c|c|c|}
\hline AUTHORS & YEAR & JOURNAL & TYPE & AIM OF RESEARCH & RELEVANCE OF AC & METHODOLOGY & SAMPLE & VARIABLES & FINDINGS & $\begin{array}{l}\text { FUTURE RESEARCH } \\
\text { AGENDA }\end{array}$ \\
\hline Rhee, $J \mathrm{H}$ & 2008 & $\begin{array}{l}\text { ASIAN BUSINESS \& } \\
\text { MANAGEMENT }\end{array}$ & $\begin{array}{l}\text { Empirical } \\
\text { article }\end{array}$ & $\begin{array}{l}\text { What are the } \\
\text { determinants } \\
\text { of entry mode } \\
\text { choice and } \\
\text { internationalization } \\
\text { performance of new } \\
\text { ventures? }\end{array}$ & $\begin{array}{l}\text { To match the } \\
\text { information- } \\
\text { processing } \\
\text { requirement } \\
\text { inherent in firm } \\
\text { internationalization, } \\
\text { employees need to } \\
\text { have a corresponding } \\
\text { information- } \\
\text { processing capacity. }\end{array}$ & Survey & $\begin{array}{l}95 \text { Korean } \\
\text { venture firms } \\
\text { that had } \\
\text { international } \\
\text { operations }\end{array}$ & $\begin{array}{l}\text { DV: Entry mode, } \\
\text { performance } \\
\text { IV: Competitive } \\
\text { advantages } \\
\text { based on } \\
\text { technology, } \\
\text { Start-up team } \\
\text { members' } \\
\text { social network, } \\
\text { Employees' } \\
\text { absorptive } \\
\text { capacity } \\
\text { CV: Firm size }\end{array}$ & $\begin{array}{l}\text { The results indicate that } \\
\text { the AC of employees } \\
\text { is not as impoortant as } \\
\text { the social networks of } \\
\text { start-up team members } \\
\text { in determining entry } \\
\text { mode in international } \\
\text { expansion. Social } \\
\text { networks of startup } \\
\text { team members do not } \\
\text { help their ventures reap } \\
\text { superior performance. }\end{array}$ & $\begin{array}{l}\text { Further theoretical } \\
\text { perspectives need to } \\
\text { be applied to better } \\
\text { understand the } \\
\text { internationalization } \\
\text { of new ventures. }\end{array}$ \\
\hline Nielsen, $\mathrm{K}$ & 2015 & $\begin{array}{l}\text { JOURNAL OF } \\
\text { TEEHNOLGGY } \\
\text { TRANSFER }\end{array}$ & $\begin{array}{l}\text { Empirical } \\
\text { article }\end{array}$ & $\begin{array}{l}\text { What is the } \\
\text { importance of } \\
\text { human capital for } \\
\text { industry choice } \\
\text { and subsequent } \\
\text { performance of first- } \\
\text { time entrepreneurs? }\end{array}$ & $\begin{array}{l}\text { Individuals with higher } \\
\text { levels of education } \\
\text { are expected to be } \\
\text { better at adapting } \\
\text { to a changing } \\
\text { environment } \\
\text { because of } \\
\text { their higher absorptive } \\
\text { and learning } \\
\text { capacities. }\end{array}$ & $\begin{array}{l}\text { Survey, OLS } \\
\text { regressions, } \\
\text { ordered logit } \\
\text { model (OLM) }\end{array}$ & $\begin{array}{l}1,151 \\
\text { individuals } \\
\text { starting new } \\
\text { ventures in } \\
13 \text { different } \\
\text { industries }\end{array}$ & $\begin{array}{l}\text { OV: New } \\
\text { venture } \\
\text { performance } \\
\text { IV: Humanan } \\
\text { capital } \\
\text { CV: Tolerance } \\
\text { of ambiguity, } \\
\text { Creativity, Social } \\
\text { capital, Wealth } \\
\text { and initial } \\
\text { investment }\end{array}$ & $\begin{array}{l}\text { Technical academics are } \\
\text { found to perform better } \\
\text { in both profitable and } \\
\text { uncertrain industries, } \\
\text { whereas non-technical } \\
\text { academics perform } \\
\text { better only in profitable } \\
\text { industries. Both types } \\
\text { of academics are more } \\
\text { likely to enter uncertain } \\
\text { industries. }\end{array}$ & $\begin{array}{l}\text { Further research } \\
\text { might explore } \\
\text { the causes of } \\
\text { the differences } \\
\text { in performance } \\
\text { between technical } \\
\text { and non-technical } \\
\text { academics in } \\
\text { uncertain industry } \\
\text { environments with } \\
\text { the intention of } \\
\text { improving university } \\
\text { entrepreneurship } \\
\text { policy and education. } \\
\text { Exploring the } \\
\text { relationship between } \\
\text { higher education } \\
\text { in different fields } \\
\text { of studury and the } \\
\text { adaptive capabilities, } \\
\text { causal//ffectual } \\
\text { reasoning regarding } \\
\text { the start-up process, } \\
\text { intrinsic/lextrinsic } \\
\text { work values, and } \\
\text { entrepreneurial } \\
\text { opportunity costs } \\
\text { would be valuable. }\end{array}$ \\
\hline $\begin{array}{l}\text { Javalgi, RG; } \\
\text { Hall, KD; } \\
\text { Cavusgiil, } \\
\text { st }\end{array}$ & 2014 & $\begin{array}{l}\text { INTERNATIONAL } \\
\text { BUSINESS REVIEW }\end{array}$ & $\begin{array}{l}\text { Conceptual } \\
\text { article }\end{array}$ & $\begin{array}{l}\text { How sales } \\
\text { representatives can } \\
\text { contribute to or even } \\
\text { largely fulfill the } \\
\text { research function? }\end{array}$ & $\begin{array}{l}\text { The degree to which } \\
\text { AC contributes } \\
\text { to producing } \\
\text { a meaningul and } \\
\text { valuable knowledge } \\
\text { advantage for the firm. }\end{array}$ & $\begin{array}{l}\text { Literature Review. } \\
\text { Conceptual model }\end{array}$ & - & - & $\begin{array}{l}\text { The authors propose } \\
\text { that international sales } \\
\text { performance for firms } \\
\text { practicing corporate } \\
\text { entrepreneurship will } \\
\text { be enhanced when } \\
\text { salespeople practice } \\
\text { customer-oriented } \\
\text { selling and the firm's } \\
\text { absorptive capacity is } \\
\text { stronger. }\end{array}$ & $\begin{array}{l}\text { Empirical testing } \\
\text { of the conceptual } \\
\text { model. Adddituonal } \\
\text { opportunity lies in } \\
\text { the investigation of } \\
\text { the incentive and } \\
\text { control structures } \\
\text { that would best } \\
\text { balance salesperson } \\
\text { independence } \\
\text { with customer- } \\
\text { oriented selling } \\
\text { and information } \\
\text { sharing. }\end{array}$ \\
\hline Un, CA & 2011 & $\begin{array}{l}\text { INTERNATIONAL } \\
\text { JOURNAL OF } \\
\text { TECHNOLOGY } \\
\text { MANAGEMENT }\end{array}$ & $\begin{array}{l}\text { Empirical } \\
\text { article }\end{array}$ & $\begin{array}{l}\text { How existing } \\
\text { capabilities influence } \\
\text { new entrepreneurial } \\
\text { technological } \\
\text { capabilities, } \\
\text { and in what } \\
\text { way the existing } \\
\text { capabilities affect } \\
\text { the development of } \\
\text { new technological } \\
\text { capabilities. }\end{array}$ & $\begin{array}{l}\text { AC enables the } \\
\text { development of new } \\
\text { knowledge. }\end{array}$ & Survey & $\begin{array}{l}1,215 \\
\text { manufacturing } \\
\text { firms operating } \\
\text { in Spain }\end{array}$ & $\begin{array}{l}\text { DV: } \\
\text { development } \\
\text { of new } \\
\text { technological } \\
\text { capabilities } \\
\text { through } \\
\text { investments } \\
\text { in R\&D } \\
\text { IV: the capability } \\
\text { to invest and } \\
\text { the capability to } \\
\text { absorb } \\
\text { CV: firm's size, } \\
\text { experience in } \\
\text { business, and } \\
\text { industry. }\end{array}$ & $\begin{array}{l}\text { Prior capabilitities } \\
\text { to invest and to } \\
\text { absorb enable the } \\
\text { firm to develop } \\
\text { new technological } \\
\text { capabilitites. The } \\
\text { capability to absorb } \\
\text { affects both types } \\
\text { of investment, the } \\
\text { capability to invest } \\
\text { only affects external } \\
\text { investments in R\&D. }\end{array}$ & $\begin{array}{l}\text { Further analyses } \\
\text { about the origin of } \\
\text { the resources and } \\
\text { capabilities, how } \\
\text { they are developed, } \\
\text { and why competitors } \\
\text { cannot imitate } \\
\text { them. }\end{array}$ \\
\hline
\end{tabular}

\section{Abstrakt}

Cel: Kilku uczonych wskazało, że zdolność absorpcyjna (AC) ma kluczowe znaczenie dla procesu innowacji $w$ dużych firmach. Jednak wielu innych autorów uważa startupy za kluczowe czynniki napędzajqce innowacje w obecnej gospodarce światowej. Dlatego niniejszy artykut ma na celu określenie, w jaki sposób koncepcja AC zostata potraktowana w kontekście nowego przedsięwzięcia. Metodyka: Systematyczny przeglad literatury analizujqcy 220 artykułów opublikowanych w latach 2001-2018. Wyniki: Systematyczny przeglqd literatury identyfikuje trzy grupy badań dotyczqcych AC w start-upach: wiedza, innowacje i wyniki wraz z głównymi autorami dyskusji, głównymi wkładami, odniesienia teoretyczne i wytyczne dotyczqce ich przyszłego programu badawczego. Implikacje dla teorii i praktyki: Niniejsze badanie wnosi wkład do literatury dotyczqcej innowacji i przedsiębiorczości łączq̨c znaczenie AC i tworzenia nowych przedsięwzięć oraz zapewniajqc lepsze zrozumienie, w jaki sposób przedsiębiorcy mogq usprawnić swoje procesy innowacyjne. Oryginalność i wartość: Na podstawie analizy przeglqdu literatury stworzono ramy różnicujq̨e strategie pozyskiwania wiedzy dla nowych przedsięwzięć. Ramy kategoryzujq strategie według 
źródła wiedzy (tj. wewnętrznego lub zewnętrznego) oraz stopnia intencjonalności (tj. formalnej lub nieformalnej).

Słowa kluczowe: innowacje, chłonność, startupy, nowe przedsięwzięcia, przedsiębiorczość.

\section{Biographical notes}

Ximena Alejandra Flechas Chaparro is a Ph.D. candidate in administration at the School of Economics, Business Administration and Accounting, University of São Paulo, Brazil (FEA-USP). She received an undergraduate degree in industrial design from the National University of Colombia of Bogotá, Colombia. Her research interests include entrepreneurship, innovation, entrepreneurial decisions, and pivots in startups. She can be contacted at xaflechas@usp.br

Ricardo Kozesinski is a Ph.D. candidate in administration at the School of Economics, Business Administration and Accounting, University of São Paulo, Brazil (FEA-USP). He has a master's degree in administration at FEA-USP. His research interests include innovation and startups. He can be contacted at ricardo@rika.com.br

Alceu Salles Camargo Júnior is an Associate Professor at the Faculty of Economics, Administration, and Accounting, University of São Paulo, Brazil (FEA-USP). He is a graduate of Naval Engineering from University of São Paulo, has a master's degree in Naval and Oceanic Engineering from University of São Paulo, and a Ph.D. in Administration from University of São Paulo. He has experience in Administration, focusing on Administration of the Production, acting on the following subjects: New product and process management, quantitative methods in administration, consumer behavior, economic result, and risk in retail administration. He can be contacted at alceu@usp.br

\section{Conflicts of interest}

The authors declare no conflict of interest.

\section{Citation (APA Style)}

Flechas Chaparro, X.A., Kozesinski, R., \& Salles Camargo Júnior, A. (2021). Absorptive capacity in startups: A Systematic literature review. Journal of Entrepreneurship, Management and Innovation, 17(1), 57-95. https://doi. org/10.7341/20211712 